\author{
박현수 $*$ 백만기·남정권 · 신운철·정종민·이건미·박슬기·김춘송·조영찬 · 김보경 \\ 농촌진흥청 국립식량과학원
}

\title{
Development and Characterization of Breeding Materials with Diverse Grain Size and Shape in japonica Rice
}

\author{
Hyun-Su Park*, Man-Kee Baek, Jeong-Kwon Nam, Woon-Cheol Shin, Jong-Min Jeong, Gun-Mi Lee, \\ Seul-Gi Park, Choon-Song Kim, Young-Chan Cho, and Bo-Kyeong Kim \\ National Institute of Crop Science, RDA, Wanju, 55365, Korea
}

\begin{abstract}
To diversify the grain size and shape of japonica rice, we developed the Breeding Materials with Diverse Grain Size and Shape (BM_DGS) and characterized the grain and yield-related traits. We used the donor parents Jizi1560 and Jizi1581, japonica germplasm with extremely large grain size. Four cross combinations between the each donor parents and Korean high yielding japonica rice cultivars, Deuraechan and Boramchan, were constructed and anther culture method was applied. Among 290 doubled haploid lines, we selected 91 elite lines with diverse grain size and shape and designated to the BM_DGS. The grain size and shape of BM_DGS exhibited beyond the characteristics of previously developed Korean rice cultivars. The alleles of major grain-related genes, GW2, GS3, and $q S W 5$, in BM_DGS showed two types, wild type or loss-of-function mutant type. The loss-of-function mutant alleles, $g w 2$, gs 3 , and $q s w 5$, had an effect on increasing grain size. The phenotypic variation of grain length was mostly controlled by GS3 alleles, and grain width and thickness were influenced by the combinations of GW2 and $q S W 5$ alleles. 1,000-grain weight was determined by the combinations of GW2, GS3, and qSW5. The grain-related genes influenced the phenotypic variation of yield-related traits. The result of this study could be useful to elucidate the relationship between the grain-related genes and agronomic traits. And the BM_DGS are being utilized in the breeding programs to diversify the grain size and shape in japonica rice.
\end{abstract}

Keywords : Rice, Grain size and shape, GW2, GS3, qSW5

\section{서 언}

벼 낟알의 크기와 형태는 수량과 품질에 중요한 역할을 한다. 낟알의 크기와 형태는 낟알의 길이, 너비, 너비에 대한 길이의 비인 장폭비와 두께에 의해 결정된다(Zuo and Li 2014). 낟알의 크기는 낟알의 무게와 직접적으로 관련되어 있으며, 낟알의 무게 는 수수, 수당립수, 등숙능력과 함께 수량을 결정하는 필수 요인 이다(Xing and Zhang 2010). 낟알의 형태는 일반적으로 낟알의 길이와 장폭비에 의해 결정되는데 쌀에 대한 소비자의 선호와 분상질과 같은 외관 품질에 영향을 미친다(Fitzgerald et al.

*Corresponding Author (E-mail: mayoe@korea.kr, Tel: +82-63-2 38-5216, Fax: +82-63-238-5205)

(Received on September 25, 2017. Accepted on November 7, 2017.)
2009). 낟알의 크기와 형태는 벼 육종사업의 중요 형질로 나라와 인종, 문화, 성별 및 연령, 사회 요구와 시대 흐름 등에 의해 목표 형질 값과 그 중요성이 변화하게 된다. 낟알의 크기와 형태 는 여러 유전자가 관여하여 조절되는 양적형질로 지금까지 약 400여개가 넘는 많은 양적형질유전자좌(quantitative trait loci; 이하 QTL)가 12 개 염색체 전반에 걸쳐서 탐색되었다(Huang et al. 2013). 이들 중 클로닝되어 그 위치와 기능이 밝혀진 QTL은 GS3(Fan et al. 2006), GW2(Song et al. 2007), $q S W 5 / G W 5$ (Shomura et al. 2008, Weng et al. 2008), GS5(Li et al. 2011), GL3/GL3.1(Qi et al. 2012), GW8(Wang et al. 2012), TGW6(Ishimaru et al. 2013), GW7(Wang et al. 2015) 등 소수이다. 최초로 클로닝된 $G S 3$ 는 낟알의 길이와 무게에 주동으로 작용하는 유전자로 $\mathrm{N}$ 말단에 기관 크기 조절(OSR; 
organ size regulation) 도메인이 존재하고 $\mathrm{C}$ 말단으로 transmembrane 도메인, TNFR/NGFR (a tumor necrosis factor receptor/nerve growth factor receptor like) 도메인, $\mathrm{VWFC}$ (a von Willebrand factor type C) 도메인이 존재한다(Mao et al. 2010). GS3 유전자는 낟알 길이에 부의 조절 작용(negatively regulator)을 하는데, OSR 도메인의 기능상실이나 결실은 긴 낟알을 특성을 가져온다. 특히 긴 낟알을 가지는 벼들과 짧은 낟알을 가지는 벼들의 GS3의 염기서열을 비교한 결과 긴 낟알을 가진 벼들은 2 번 엑손의 시스테인 코돈(TGC)이 종결코돈(TGA) 으로 넌센스 돌연변이가 일어난 것으로 확인되었다(Fan et al. 2009). GW2는 낟알의 너비와 폭에 관여하는 주동 QTL로 RING-type E3 ubiquitin ligase를 부호화한다(Song et al. 2007). $G W 2$ 유전자의 4 번 엑손에서 1 개의 염기가 결실될 경우 단백질 생성이 조기종결되어 유전자의 기능을 상실하게 된다. $G W 2$ 는 세포 분열에 부의 조절 작용을 하는데, $G W 2$ 의 기능 상실은 소수 왕겨의 세포수 증가와 등숙속도의 향상을 가져와 낟알의 너비, 무게와 수량을 증가시킨다. $q S W 5$ 와 $G W 5$ 는 5번 염색체에서 낟알의 너비와 무게에 관여하는 동일 주동 QTL로 밝혀졌다. $q S W 5 / G W 5$ 는 polyubiquitin과 상호작용하는 아직까지 밝혀지지 않은 단백질을 부호화하며 세포분열을 조절하는 ubiquitine-proteosome pathway 에 작용한다(Weng et al. 2008). 대부분의 자포니카 벼에서 발견되 는 qSW5 유전자 염기서열의 1212-bp 결실은 유전자의 기능상실을 가져오고 이로 인해 낟알의 너비가 길어지고 무게가 증가하게 된다 (Shomura et al. 2008)

우리나라, 일본, 중국 동북지역의 사람들은 대부분 쌀이 짧고 둥근 단원형을 선호하는 반면, 동남아시아, 중국 남부, 아메리카, 유럽 지역의 사람들은 길고 얇은 형태의 쌀을 선호한다 (Calingacion et al. 2014). 특히 우리나라 소비자는 밥이 차지며 끈기가 있는 자포니카형 쌀을 선호하는데, 찰기가 많은 자포니카 형 벼들은 대부분 쌀의 크기가 작고 길이가 짧으며 형태가 둥근 단립종의 단원형의 입형을 가지고 있으며, 찰기가 상대적으로 떨어지는 인디카형 벼는 쌀의 길이가 길고 너비가 얇은 장립종의 세장형 입형을 가지고 있다(Juliano 1979, Kang et al. 2006). 생태형 특유의 입형 특성은 우리나라 쌀 산업과 소비자의 중소립 단원형 입형 선호를 가져왔고, 인디카/자포니카 교잡을 통해 수량성을 향상시키고자 개발된 통일형 품종들에서 조차 단원형 입형을 가진 품종을 육성하고자 노력을 경주할 정도(Lee et al. 2003)로 우리나라 벼 육종사업에서 중소립 단원형 입형은 중요 목표 형질 특성이었다. 이러한 강한 선발압으로 인하여 입형 형질에 대한 우리나라 자포니카 벼 품종의 유전적 다양성은
협소화되었고, 중소립 단원형 이외의 입형에 대한 새로운 사회 요구와 시대적 변화에 직면할 경우 신속하고 능동적인 육종사업 을 수행하는데 어려움이 예상되고 있다. 또한 정체되어 있는 자포니카 벼의 수량성 장벽과 기후변화에 따른 품질저하 문제를 극복하기 위한 기반연구로서 우리나라 자포니카 벼의 입형 다양 화 연구는 중요성이 매우 크다.

본 연구는 우리나라 자포니카 벼의 협소한 입형 특성을 다양화 하고자 자포니카 대립형 유전자원을 교배모본으로 활용하여 약배양을 통해 조기에 입형이 다양화된 육종소재를 개발하고 이들의 입형 관련 유전자형과 형질 특성을 분석하여 자포니카 벼 입형 다양화 육종사업에 반영하고자 수행하였다.

\section{재료 및 방법}

\section{시험재료 및 재배방법}

자포니카 벼의 입형 특성을 다양화하기 위해 자포니카 극대립 유전자원 Jizi1560 (IT251540)과 Jizi1581 (IT251541) (Qi et al. 2012, Ying et al. 2012)을 수여친으로 이용하였다. 수량성 향상을 위해 우리나라 자포니카 초다수 품종인 드래찬(Ha et al. 2009)과 보람찬(Ha et al. 2012)을 대립 유전자원과 각각 인공교배하여 4 개의 $\mathrm{F}_{1}$ 조합을 작성하였다. 조기에 고정된 계통 을 획득하고자 $\mathrm{F}_{1}$ 식물체를 이용하여 약배양을 수행하였다. 약배 양 계통 중 열악형질을 가진 계통을 제외한 290개 계통을 선발하 였고 교배모본과 우리나라 대립형 품종인 '대립벼 1호' (Choi et al. 1994)를 비교품종으로 이용하여 농촌진흥청 국립식량과학 원 벼 시험포장에 2013년 4월 30일 파종하여 5월 30일에 30 x $15 \mathrm{~cm}$ 로 주당 1 본씩 조당 28 주를 이앙하여 포장평가를 수행하 였다. 290 개 약배양 계통 중 포장평가를 통해 입형 특성이 다양화 된 91개 계통을 선발하였으며, 교배모본과 대립벼1호를 포함한 96개 자원에 대해서 2014년과 2016년 2년간 완전임의배치법 2반복으로 4월 30일 파종하고 5월 30일에 $30 \times 15 \mathrm{~cm}$ 로 주당 1 본씩 조당 28 주를 이앙하여 예비선발시험을 수행하였다. 시비 량은 N-P $\mathrm{P}_{2} \mathrm{O}_{5}-\mathrm{K}_{2} \mathrm{O}$ 를 90-45-57 kg/ha으로 질소는 기비 : 분얼비 : 수비를 $50: 20: 30$ 비율로 분시하였고, 인산은 전량 기비로, 칼륨은 기비 : 수비를 $70: 30$ 비율로 분시하였다.

\section{농업형질 조사}

2013년 포장시험과 2014, 2016년 예비선발시험에 공시된 재료의 출수기를 조사하고 성숙기에 평균이 되는 5 개체에 대해 서 간장, 수장, 수수를 측정하였다. 공시재료를 수확한 후 충실히 
Table 1. The information of markers used for the identification of grain-related genes, GW2, GS3, and $q S W 5$.

\begin{tabular}{|c|c|c|c|c|c|}
\hline Gene & $\begin{array}{l}\text { Chromo- } \\
\text { some }\end{array}$ & Marker & Sequence $\left(5^{\prime}-3^{\prime}\right)$ & $\begin{array}{l}\text { Product size } \\
\text { (bp) }\end{array}$ & Reference \\
\hline$G W 2$ & 2 & GW2-Hpa I & $\begin{array}{l}\text { F: CCAATAAAGATGTCCATTCTGTTA } \\
\text { R: GCTCTTCCTGTAACACATATTATG }\end{array}$ & $\begin{array}{c}23+151 / 174 \\
(\mathrm{dCAPS} / \text { Hpa I ) }\end{array}$ & $\begin{array}{l}\text { Yan et al. } 2009 \\
\text { Yan et al. } 2011\end{array}$ \\
\hline$G S 3$ & 3 & GS3-Pst I & $\begin{array}{l}\text { F: TATTTATTGGCTTGATTTCCTGTG } \\
\text { R: GCTGGTTTTTTACTTTCATTTGCC }\end{array}$ & $\begin{array}{c}294+218 / 512 \\
(\text { CAPS/Pst I ) }\end{array}$ & $\begin{array}{l}\text { Yan et al. } 2009 \\
\text { Yan et al. } 2011\end{array}$ \\
\hline$q S W 5$ & 5 & N1212del & $\begin{array}{l}\text { F: CGTCTTGCAACCAACGCCGATGTTATAC } \\
\text { R: GAGCGTGTGTAGGGAAGGAGCTGCATGA }\end{array}$ & $\begin{array}{l}\text { 759/1021/1971 } \\
\quad \text { (Indel) }\end{array}$ & $\begin{array}{l}\text { Shomura et al. } 2008 \\
\text { Yan et al. } 2011\end{array}$ \\
\hline
\end{tabular}

등숙된 정조와 현미를 정선하여 정조와 현미의 길이, 너비, 두께 를 캘리퍼스(caliper CD-15CP, Mitutoyo Corp., Japan)를 이용 하여 각각 5 립씩 조사하고 너비에 대한 길이의 비율로 장폭비를 계산하였다. 정조와 현미 100 립에 대한 무게를 3 반복으로 측정 하여 평균 값을 천립중으로 환산하였다. 예비선발시험에 공시된 재료는 성숙기에 3 주를 예취하여 등숙률 및 수당립수를 조사하 고 20 주를 예취하여 정조중을 측정하였다. 예비선발시험 2년간 의 평균 값을 입형 및 수량 관련 형질 값으로 활용하였다.

\section{입형 관련 유전자 분석}

예비선발시험에 공시된 96개 재료에 대해서 입형 관련 유전자 와 농업형질과의 관련성을 알아보고자 유전자 분석을 수행하였 다. Genomic DNA 추출은 BioSprint 96 (Qiagen Co., Düren, Germany)을 이용하였다. 샘플을 TissueLyser II (Qiagen Co., Düren, Germany)로 마쇄한 후 BioSprint 96 DNA Plant Kit (Qiagen Co., Düren, Germany)를 이용하여 DNA를 추출하였 다. 입형 관련 유전자로 입형에 대한 기여도가 크고 특성이 자세 히 밝혀진 주동유전자 $G W 2, G S 3, q S W 5$ 을 대상으로 하였다. 분자표지는 기존의 연구결과에서 개발돼 적용되었던 GW2-Hpa I (GW2 대상), GS3-Pst I (GS3), N1212del ( $q S W 5$ )를 이용하 였다(Table 1). PCR은 $10 \mathrm{ng}$ 의 DNA와 AccuPower® PCR PreMix (Bioneer Co., Daejoen, Korea)를 이용하여 My-Genie 96 Thermal block (Bioneer Co., Daejoen, Korea)에서 수행하 였다. PCR 반응은 GW2-Hpa I 와 GS3-Pst I 는 $94^{\circ} \mathrm{C}$ 에서 4 분 간 초기변성 후 $94^{\circ} \mathrm{C} 45$ 초, $55^{\circ} \mathrm{C} 45$ 초, $72^{\circ} \mathrm{C} 1$ 분간 35 회 반복하 고 $72^{\circ} \mathrm{C}$ 에서 5 분간 반응하였다. $\mathrm{N} 1212 \mathrm{del}$ 는 $94^{\circ} \mathrm{C}$ 에서 5 분간 초기변성 후 $94^{\circ} \mathrm{C} 45$ 초, $65^{\circ} \mathrm{C} 45$ 초, $72^{\circ} \mathrm{C} 2$ 분간 30 회 반복하고 $72^{\circ} \mathrm{C}$ 에서 10 분간 반응하였다. $G W 2$ 와 $G S 3$ 의 증폭된 PCR 산물 은 제한효소 Hpa I, Pst I 를 처리하고, $q S W 5$ 는 제한효소 처리 없이 전기영동하였다. SYBR safe DNA gel stain (Invitron)으로 염색된 2\% agarose gel을 이용하여 전기영동을
수행하였고, UV transilluminator (MiniBIS Pro, DNR Bio-Imaging Systems Ltd., Jerusalem, Israel)를 활용하여 유전 자형을 판정하였다.

\section{통계분석}

통계분석은 SAS 프로그램(Version 9.2, SAS Institute Inc., Cary, NC, USA)을 이용하였다. 입형 및 수량 관련 형질에 대한 평균을 기술 통계법으로 구하였고, 평균간 비교는 $\mathrm{PROC}$ ANOVA로 분산분석 후 유의성이 있을 경우 $5 \%$ 유의수준에서 Ducan's Multiple Range Test (DMRT)로 분석하였다. 2013년 포장평가에 공시된 재료에 대해서 군집분석(PROC CLUSTER; 평균 연결법)을 수행하였다. 상관분석(PROC CORR)을 실시하 여 형질들의 관련성을 알아보고, 주성분 분석(PROC PCA)을 수행하여 입형 관련 형질과 공시재료들의 구조적 관계를 분석하 였다. 입형 관련 주동 유전자 $G W 2, G S 3, q S W 5$ 가 정조와 현미의 길이, 너비, 두께, 천립중, 수당립수, 수수, 등숙률 각각에 기여하 는 정도와 수량구성요소인 천립중, 수당립수, 수수, 등숙률이 정조 수량에 미치는 기여도를 알아보기 위해 PROC TCALIS로 경로계수 분석을 수행하였다. GW2, GS3, qSW5로 구성된 단일 유전자, 두 개 및 세 개의 유전자 조합이 입형 및 수량 관련 형질의 표현형 변이에 미치는 영향을 3 요인 분산분석(PROC $\mathrm{GLM})$ 을 이용해 분석하였다. 분산분석의 평균제곱합, $F$ 값 및 결정계수는 제 3 유형 제곱합을 이용하여 산출하였다. $t$-test(PROC TTEST)를 이용하여 GW2, GS3, qSW5 단일 유전 자의 대립유전자형간 입형 및 수량 관련 형질의 표현형 차이를 분석하였고, 1 요인 분산분석(PROC ANOVA)과 평균간 비교 (DMRT)를 통해 $G W 2, G S 3, q S W 5$ 등 세 개의 유전자로 구성된 대립유전자형 조합 간의 입형 및 수량 관련 형질의 표현형 차이를 분석하였다. 


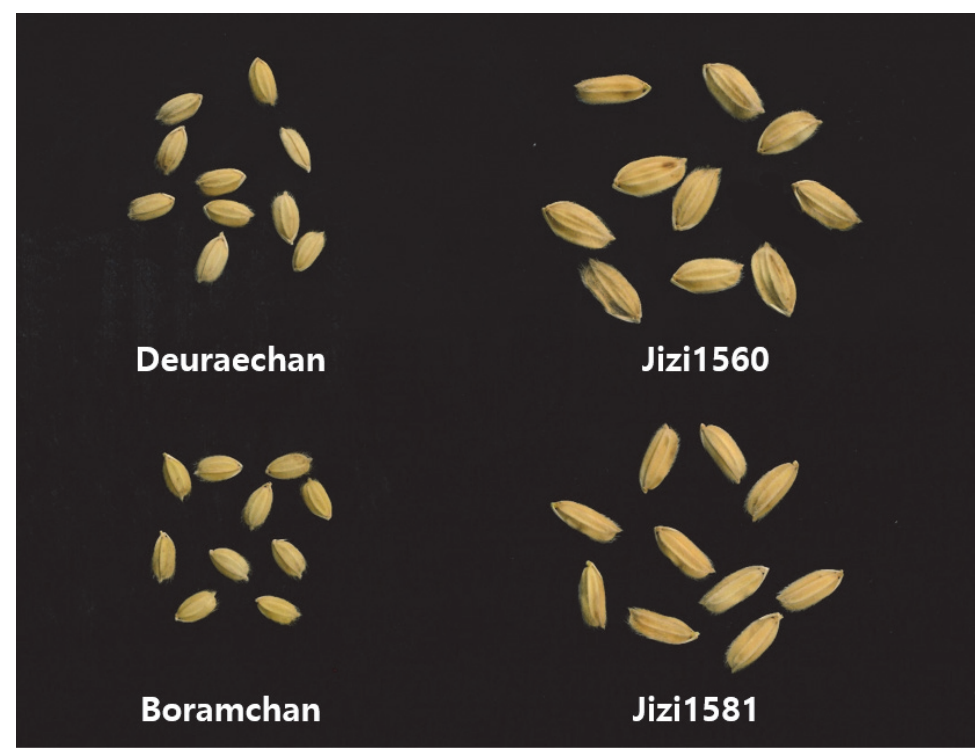

Fig. 1. Image of rough rice of the parents.

Table 2. Anther culture ability of the crosses and doubled haploid lines used in this study.

\begin{tabular}{|c|c|c|c|c|c|c|c|}
\hline Cross combination & $\begin{array}{l}\text { Anther } \\
\text { cultured } \\
\text { (no.) }\end{array}$ & $\begin{array}{c}\text { Cali } \\
\text { induced } \\
\text { (no. and \%) }\end{array}$ & $\begin{array}{c}\text { Plant } \\
\text { regeneration } \\
(\text { no. and } \%)^{z}\end{array}$ & $\begin{array}{c}\text { Green } \\
\text { plants } \\
(\text { no. and } \%)^{\mathrm{y}}\end{array}$ & $\begin{array}{c}\text { Albino } \\
(\text { no. and } \%)^{\mathrm{x}}\end{array}$ & $\begin{array}{c}\text { Doubled haploid } \\
\text { (DH) lines } \\
\text { (no. })^{\mathrm{w}}\end{array}$ & $\begin{array}{l}\text { Selected } \\
\text { DH lines } \\
(\text { no. })^{\mathrm{v}}\end{array}$ \\
\hline Deuraechan/Jizi1560 & 10,700 & $6,280(58.7)$ & $1241(19.8)$ & $146(11.8)$ & $1095(88.2)$ & 99 & 88 \\
\hline Deuraechan/Jizi1581 & 11,600 & $2,780(24.0)$ & $577(20.8)$ & $110(18.8)$ & $467(80.9)$ & 105 & 70 \\
\hline Boramchan/Jizi1560 & 11,800 & $4,320(36.6)$ & $817(18.9)$ & $112(13.7)$ & $705(86.3)$ & 72 & 62 \\
\hline Boramchan/Jizi1581 & 6,300 & $4,380(69.5)$ & $1184(27.0)$ & $228(19.3)$ & $956(80.7)$ & 84 & 70 \\
\hline Total & & & & & & 360 & 290 \\
\hline
\end{tabular}

${ }^{\mathrm{z}}$ Percent plant regeneration is the number of plants regenerated over number of cali plated

${ }^{\mathrm{y}}$ Percent green is the number of green plants regenerated over total plants regenerated

${ }^{\mathrm{x}}$ Percent albino is the number of albino plants regenerated over total plants regenerated

${ }^{\mathrm{w}}$ Double haploid lines are harvested plants having fertile grain

${ }^{v}$ Selected DH lines are used in this study

\section{결 과}

\section{자포니카 벼 입형 다양화 육종소재 개발}

우리나라 자포니카 벼의 협소한 입형 특성을 다양화하기 위해 수여친으로 이용된 Jizi1560과 Jizi1581은 자포니카형으로 낟알 의 길이가 길고 너비가 넓어 커다란 입형 특성을 가진 대립 유전자원이다(Fig. 1). 이에 반해 수량성과 재배안정성 향상을 위해 교배친으로 이용된 우리나라 자포니카 초다수 품종 드래찬 과 보람찬은 길이가 짧고 둥근 단원립 형태에 상대적으로 가벼운 입형 특성을 가지고 있다. 대립 유전자원과 초다수 품종을 인공교 배하여 4조합(드래찬/Jizi1560, 드래찬/Jizi1581, 보람찬 $/ \mathrm{Jizi} 1560$, 보람찬/Jizi1581)을 작성하였다. 조기에 고정된 계통
을 육성하고자 각 교배조합의 $\mathrm{F}_{1}$ 식물체를 이용하여 약배양을 수행하였다. 약배양을 통해 4조합에서 360 개의 약배양 계통을 얻을 수 있었으며 이중 열악형질을 가진 계통을 제외한 290개 계통을 포장평가에 이용하였다(Table 2). 290개 약배양 계통과 교배친인 Jizi1560과 Jizi1581(3반복 공시), 드래찬과 보람찬(2 반복) 및 대립벼 1 호(3반복) 등 303 개 재료를 포장평가에 공시하 여 정조 입형과 출수기 등 농업형질을 조사하였다. 정조의 입형 관련 형질 중 천립중은 정조 길이( $r=0.789)$, 너비(0.658), 두께 $(0.655)$ 순으로 관련성이 높았으며, 정조 길이는 너비(0.285)보 다는 두께 $(0.330)$ 와 관련성이 높았다(Table 3). 정조 너비는 두께와 높은 정의 상관 $(r=0.817)$ 을 나타냈으며, 정조 장폭비는 길이와 높은 정의 상관관계(0.638)를 나타냈고 너비와 두께와는 
Table 3. Relationship between the grain-related traits of the doubled haploid lines $(n=303)$.

\begin{tabular}{ccccc}
\hline Trait & GW & GT & RLW & TGW \\
\hline GL & $0.330^{* * y}$ & $0.285^{* *}$ & $0.638^{* *}$ & $0.789^{* *}$ \\
GW & & $0.817^{* *}$ & $-0.510^{* *}$ & $0.658^{* *}$ \\
GT & & $-0.399^{* *}$ & $0.655^{* *}$ \\
RLW & & & $0.174^{* *}$ \\
\hline
\end{tabular}

\footnotetext{
${ }^{\mathrm{z}} \mathrm{GL}$ : grain length, GW: grain width, GT: grain thickness, RLW: ratio of length to width, TGW: 1000-grain weight

$\mathrm{y}_{* *}$ means significant at $p<0.01$
}

부의 상관관계(-0.510, -0.399)를 나타냈다. 공시재료의 정조 길이, 너비, 두께 및 장폭비 값을 가지고 평균연결법을 통하여 군집분석을 수행하였다(Fig. 2). 군집이 평균연결법에 의해 병합 되는 과정을 살펴보면 Norm RMS Dist (표준화된 RMS 거리)가 군집이 4 개( 0.833$)$ 에서 5 개( 0.780$)$ 로 될 때 5 개에서 6개(0.681) 로 될 때보다 거리의 변화는 적었으나, 군집이 현재와 같이 묶였 을 때의 전체적인 설명 정도를 나타내는 $R^{2}$ 값이 4 개일 때 0.549 , 5 개 일 때 $0.730,6$ 개 일 때 0.758 로 군집이 5 개에서 6 개로 될 경우 설명할 수 있는 정도의 차이(2.8\%)에 비해 4 개에서 5 개로 될 경우(18.1\%)가 크게 증가하기 때문에 군집을 A-E까지 5 개의 그룹으로 나누었다(data not shown). 또한 각 그룹을 대표하는 계통을 편의 없이 선발하고자 군집분포를 고려하여 그룹을 1-7개의 소그룹으로 분류하였다. 각각의 그룹에 의한 입형 및 농업형질 값은 Table 4 와 같다. 드래찬과 보람찬이 속한 그룹 $\mathrm{C}$ 는 가장 많은 계통들이 포함되어 있었으며 다른 그룹에 비해 상대적으로 정조 길이가 짧고 장폭비가 작은 단원형 에 천립중이 작은 입형 특성을 나타냈다. 대립벼 1 호가 속한 그룹 $\mathrm{B}$ 는 두 번째로 많은 재료를 포함하고 있었으며, 그룹 $\mathrm{C}$ 에 비해 정조 길이와 너비가 길고 천립중이 무거운 특성을 나타냈다. $\mathrm{Jizi1581}$ 이 속한 그룹 $\mathrm{A}$ 는 그룹 $\mathrm{C}$ 와 $\mathrm{B}$ 에 비해 상대적으로 정조 길이가 길어 장폭비가 크고 천립중이 무거운 특성을 나타냈다. 그룹 $\mathrm{A}, \mathrm{B}, \mathrm{C}$ 는 출수기, 간장, 수중, 수수 등 농업형질 특성에서 큰 차이를 보이지 않았다. Jizi1560이 단독으로 속한 그룹 $\mathrm{D}$ 는 정조 길이, 너비, 두께, 천립중이 가장 큰 대립형 특성을 나타냈으 며, 그룹 $\mathrm{A}, \mathrm{B}, \mathrm{C}$ 에 비해 출수가 빠르고 간장과 수장은 길며 수수는 적은 특성을 나타냈다. 2 개의 약배양 계통이 속한 그룹 $\mathrm{E}$ 는 정조 길이가 긴 반면 너비는 짧아 장폭비가 가장 큰 입형 특성을 나타냈으며, 출수가 매우 늦고 간장, 수장이 길고 수수는 많은 특성을 나타냈다. 이들 계통은 낟알에 까락이 있고 탈립이 되며 지엽이 쳐지는 등 열악형질을 수반하고 있었다(data not

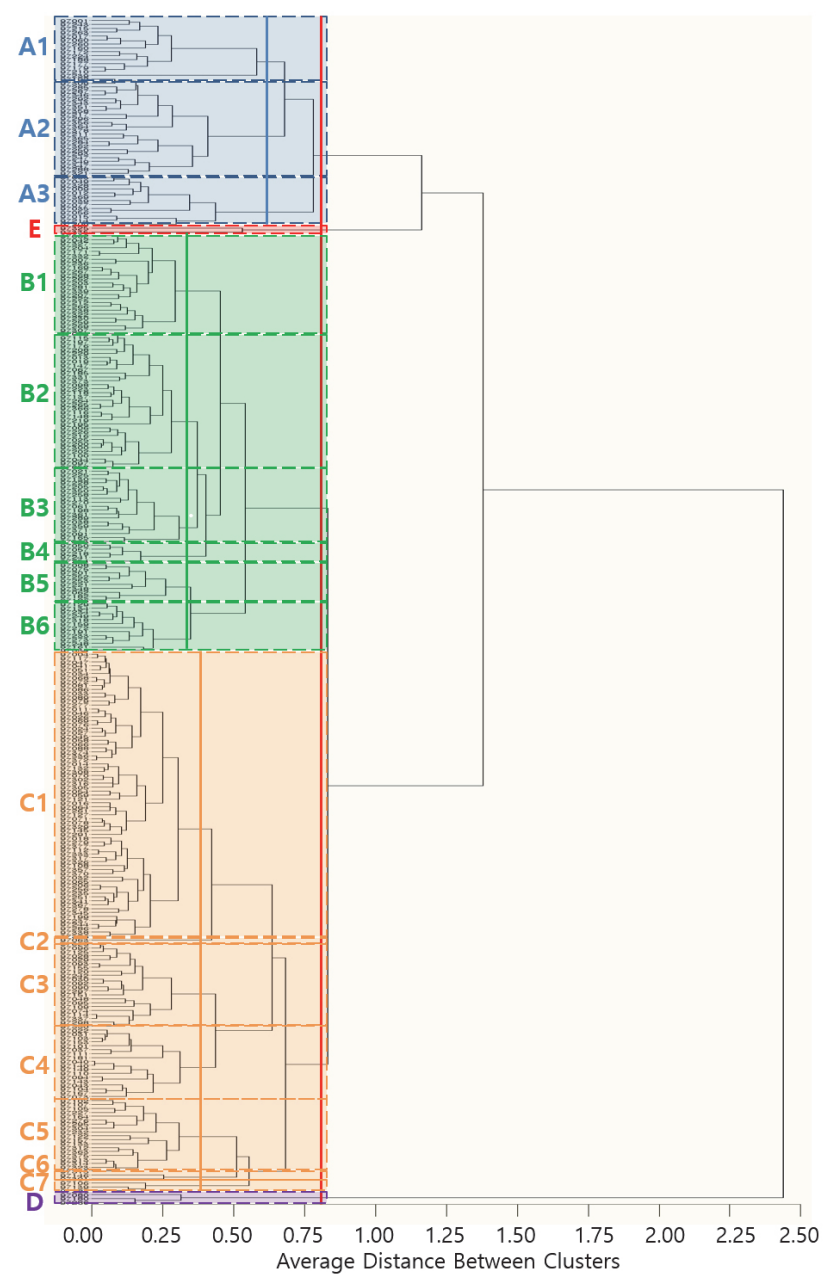

Fig. 2. Cluster analysis of doubled haploid lines based on rough rice length, width, thickness, and ratio of length to width in 2013.

shown). 포장평가에 공시된290개 약배양 계통 중 각 그룹과 소그룹을 대표하여 다양한 입형 특성을 가지고 있으면서 농업형 질 특성이 양호한 91계통을 선발하여 '자포니카 벼 입형 다양화 
Table 4. Grain-related and agronomic traits of the groups divided by cluster analysis in 2013.

\begin{tabular}{|c|c|c|c|c|c|c|c|c|c|c|c|}
\hline \multirow{2}{*}{\multicolumn{2}{|c|}{ Group }} & \multirow[b]{2}{*}{$\mathrm{n}$} & \multicolumn{5}{|c|}{ Rough rice } & \multirow{2}{*}{$\begin{array}{c}\text { HD } \\
\text { (DAS) }\end{array}$} & \multirow{2}{*}{$\begin{array}{c}\mathrm{CL} \\
(\mathrm{cm})\end{array}$} & \multirow{2}{*}{$\begin{array}{l}\text { PL } \\
(\mathrm{cm})\end{array}$} & \multirow{2}{*}{ PN } \\
\hline & & & $\begin{array}{c}\mathrm{GL}^{\mathrm{z}} \\
(\mathrm{mm})\end{array}$ & $\begin{array}{c}\text { GW } \\
(\mathrm{mm})\end{array}$ & $\begin{array}{c}\text { GT } \\
(\mathrm{mm})\end{array}$ & RLW & $\begin{array}{c}\text { TGW } \\
(\mathrm{g})\end{array}$ & & & & \\
\hline \multirow{5}{*}{ A } & A1 & 15 & $10.42 b^{y}$ & $4.08 \mathrm{c}$ & $2.54 \mathrm{~cd}$ & $2.56 \mathrm{c}$ & $46.0 \mathrm{~b}$ & $96 b c$ & $84 a b c$ & 23 bcde & 9abcd \\
\hline & $\mathrm{A} 2$ & 25 & $9.76 \mathrm{c}$ & $3.62 \mathrm{efg}$ & $2.37 \mathrm{fgh}$ & $2.70 \mathrm{~b}$ & $37.9 \mathrm{def}$ & $97 b c$ & $80 b c$ & $24 \mathrm{abc}$ & $8 \mathrm{bcd}$ \\
\hline & A3 & 13 & $9.69 \mathrm{c}$ & $4.46 b$ & $2.68 \mathrm{~b}$ & $2.18 \mathrm{f}$ & $43.3 b c$ & $104 b c$ & $80 \mathrm{bc}$ & $23 \mathrm{cde}$ & $8 \mathrm{~cd}$ \\
\hline & Mean & 53 & $9.93 C^{\mathrm{x}}$ & $3.96 \mathrm{~B}$ & $2.49 \mathrm{~B}$ & $2.53 \mathrm{~B}$ & $41.5 \mathrm{~B}$ & $98 \mathrm{~B}$ & $81 \mathrm{~B}$ & $24 \mathrm{AB}$ & $8 \mathrm{~B}$ \\
\hline & C.V.(\%) & 53 & 3.9 & 9.8 & 6.4 & 9.5 & 11.5 & 11.2 & 13.8 & 10.1 & 24.7 \\
\hline \multirow{8}{*}{ B } & B1 & 24 & $8.70 \mathrm{f}$ & $3.78 \mathrm{ef}$ & $2.40 \mathrm{efg}$ & $2.31 \mathrm{de}$ & $35.0 \mathrm{ef}$ & $96 \mathrm{bc}$ & $83 a b c$ & $23 \mathrm{cde}$ & 9abcd \\
\hline & B2 & 36 & $8.79 \mathrm{ef}$ & $4.10 \mathrm{c}$ & $2.53 \mathrm{~cd}$ & $2.15 f$ & $37.7 \mathrm{def}$ & $99 \mathrm{bc}$ & $79 b c$ & $22 \mathrm{cde}$ & $8 a b c d$ \\
\hline & B3 & 19 & $8.44 \mathrm{~g}$ & $4.21 \mathrm{c}$ & $2.60 b c$ & $2.01 \mathrm{~g}$ & $37.1 \mathrm{def}$ & $101 b c$ & $77 b c$ & $23 \mathrm{cde}$ & 8abcd \\
\hline & B4 & 5 & $8.97 \mathrm{e}$ & $4.52 \mathrm{~b}$ & $2.61 b c$ & $1.98 \mathrm{gh}$ & $38.3 \mathrm{de}$ & $105 \mathrm{bc}$ & $72 \mathrm{c}$ & $22 \mathrm{cde}$ & $8 \mathrm{bcd}$ \\
\hline & B5 & 10 & $9.32 \mathrm{~d}$ & $4.15 c$ & $2.50 \mathrm{cde}$ & $2.25 \mathrm{ef}$ & $40.1 \mathrm{~cd}$ & $109 \mathrm{~b}$ & $89 a b$ & $26 a$ & $7 d$ \\
\hline & B6 & 13 & $9.23 \mathrm{~d}$ & $3.81 \mathrm{de}$ & $2.37 \mathrm{fgh}$ & $2.43 \mathrm{~d}$ & $35.9 \mathrm{ef}$ & $95 \mathrm{bc}$ & $76 b c$ & $23 \mathrm{cde}$ & $9 \mathrm{abcd}$ \\
\hline & Mean & 107 & $8.82 \mathrm{D}$ & $4.04 \mathrm{~B}$ & $2.49 \mathrm{~B}$ & $2.20 \mathrm{C}$ & $37.0 \mathrm{C}$ & $99 \mathrm{~B}$ & $80 \mathrm{~B}$ & $23 \mathrm{~B}$ & $8 \mathrm{~B}$ \\
\hline & C.V.(\%) & 107 & 3.6 & 5.9 & 4.8 & 7.3 & 9.3 & 13.1 & 15.3 & 10.5 & 21.2 \\
\hline \multirow{9}{*}{$\mathrm{C}$} & $\mathrm{C} 1$ & 73 & $8.10 \mathrm{~h}$ & $4.01 \mathrm{~cd}$ & $2.53 \mathrm{~cd}$ & $2.03 \mathrm{~g}$ & $34.2 \mathrm{f}$ & $97 b c$ & $75 b c$ & $22 \mathrm{cde}$ & 9abcd \\
\hline & $\mathrm{C} 2$ & 1 & $7.59 \mathrm{i}$ & $4.05 \mathrm{c}$ & $2.42 \mathrm{def}$ & $1.88 \mathrm{~h}$ & $30.2 \mathrm{~g}$ & $106 \mathrm{~b}$ & $80 \mathrm{bc}$ & $20 \mathrm{e}$ & 9abcd \\
\hline & $\mathrm{C} 3$ & 22 & $7.77 \mathrm{i}$ & $3.63 \mathrm{efg}$ & $2.34 \mathrm{fgh}$ & $2.15 f$ & $29.3 \mathrm{~g}$ & $97 b c$ & $75 b c$ & $22 \mathrm{cde}$ & 9abcd \\
\hline & $\mathrm{C} 4$ & 18 & $7.19 \mathrm{j}$ & $3.59 \mathrm{fg}$ & $2.34 \mathrm{fgh}$ & $2.01 \mathrm{~g}$ & $27.0 \mathrm{~g}$ & $100 \mathrm{bc}$ & $76 b c$ & $21 \mathrm{de}$ & $10 \mathrm{abc}$ \\
\hline & $\mathrm{C} 5$ & 19 & $8.22 \mathrm{gh}$ & $3.44 \mathrm{gh}$ & 2.29ghi & $2.40 \mathrm{~d}$ & $29.8 \mathrm{~g}$ & $105 \mathrm{bc}$ & $83 a b c$ & $23 \mathrm{bcde}$ & 9abcd \\
\hline & C6 & 2 & $7.68 \mathrm{i}$ & $3.16 \mathrm{ij}$ & $2.09 \mathrm{j}$ & $2.43 \mathrm{~d}$ & $23.5 \mathrm{~h}$ & $98 \mathrm{cb}$ & $72 \mathrm{c}$ & $21 \mathrm{e}$ & $10 \mathrm{abc}$ \\
\hline & $\mathrm{C} 7$ & 3 & $8.80 \mathrm{ef}$ & 3.30hi & $2.20 \mathrm{i}$ & $2.67 b c$ & $29.9 \mathrm{~g}$ & $109 \mathrm{~b}$ & $79 b c$ & $22 \mathrm{cde}$ & $9 \mathrm{abcd}$ \\
\hline & Mean & 138 & $7.95 \mathrm{E}$ & $3.79 \mathrm{~B}$ & $2.43 \mathrm{~B}$ & $2.11 \mathrm{C}$ & $31.6 \mathrm{D}$ & $99 \mathrm{~B}$ & $76 \mathrm{~B}$ & $22 B$ & $9 \mathrm{AB}$ \\
\hline & C.V.(\%) & 138 & 5.0 & 7.9 & 5.8 & 8.5 & 11.7 & 10.1 & 11.8 & 8.7 & 17.8 \\
\hline \multirow{2}{*}{$\mathrm{D}$} & $\mathrm{D}$ & 3 & $11.56 \mathrm{aA}$ & $5.26 \mathrm{aA}$ & $2.97 \mathrm{aA}$ & $2.20 \mathrm{efC}$ & $55.3 \mathrm{aA}$ & $89 \mathrm{cB}$ & $83 \mathrm{abcAB}$ & 24abcdAB & $8 \mathrm{cdB}$ \\
\hline & C.V.(\%) & 3 & 1.5 & 3.6 & 1.7 & 2.7 & 2.9 & 0.0 & 3.4 & 8.5 & 13.2 \\
\hline \multirow{2}{*}{$\mathrm{E}$} & $\mathrm{E}$ & 2 & $10.60 \mathrm{bB}$ & $3.07 \mathrm{jC}$ & $2.27 \mathrm{hiC}$ & $3.45 \mathrm{aA}$ & $35.0 \mathrm{eCD}$ & $125 \mathrm{aA}$ & $95 \mathrm{aA}$ & $26 \mathrm{abA}$ & $11 \mathrm{aA}$ \\
\hline & C.V.(\%) & 2 & 4.8 & 1.6 & 2.6 & 3.2 & 1.2 & 0.0 & 3.3 & 0.8 & 41.7 \\
\hline \multirow{2}{*}{ Total } & Mean & 303 & 8.66 & 3.91 & 2.47 & 2.23 & 35.5 & 99 & 78 & 23 & 9 \\
\hline & C.V.(\%) & 303 & 10.2 & 9.0 & 6.1 & 11.7 & 16.0 & 12.1 & 13.8 & 10.2 & 20.7 \\
\hline
\end{tabular}

${ }^{\mathrm{z}} \mathrm{GL}$ : grain length, GW: grain width, GT: grain thickness, RLW: ratio of length to width, TGW: 1000-grain weight, HD: heading date, DAS: days after seeding, CL: culm length, PL: panicle length, PN: number of panicles per hill

${ }^{\mathrm{y}}$ Means with the same letters in a column are not significantly different at $p<0.05$ (ANOVA followed by DMRT)

${ }^{\mathrm{x}}$ Capital letters indicate statistic difference among main groups defined by culstering analysis

육종소재(이하 ‘입형 다양화 육종소재')’라 명명하고 예비선발 시험에 공시하여 추가분석을 수행하였다.

\section{입형 다양화 육종소재의 입형 관련 형질 특성}

입형 다양화 육종소재의 2 년간 예비선발시험에서 정조와 현 미의 평균 입형 관련 형질 값은 Table 5과 같다. Jizi1581을 포함하는 그룹 $\mathrm{A}$ 와 대립벼 1 호를 포함하는 그룹 $\mathrm{B}$ 는 비슷한 낟알 너비를 나타냈으며, 그룹 $\mathrm{A}$ 의 낟알 길이가 더 길고 천립중이 더 무거웠다. 드래찬과 보람찬을 포함하는 그룹 $\mathrm{C}$ 는 다른 그룹에 비해 낟알이 짧고 둥근 단원형의 중소립 입형 특성을 나타냈으며,
Jizi1560만 속한 그룹 $\mathrm{D}$ 는 낟알의 길이, 너비, 두께와 천립중의 형질 값이 가장 큰 대립형 특성을 나타냈다. 그룹 $\mathrm{E}$ 는 두 개의 약배양 계통(DGS79, DGS83)을 포함하는데 낟알의 길이가 길 고 폭이 좁아 장폭비가 가장 큰 입형 특성을 나타냈다. 입형 다양화 육종소재의 입형 관련 형질간의 구조적 관계와 공시재료 의 분포를 알아보고자 정조와 현미의 입형 관련 형질 값을 이용하 여 주성분 분석을 수행하였다(Table 6). 축소된 형질들의 주성분 1 은 전체 형질 특성의 $56.4 \%$ 를 설명할 수 있었으며 주성분 2 는 $37.5 \%$ 를 설명할 수 있어 이들 2 개의 주성분으로 전체 형질의 $93.9 \%$ 를 설명할 수 있었다. 주성분 분포도를 통해 형질들의 
Table 5. Grain-related traits of the breeding materials.

\begin{tabular}{|c|c|c|c|c|c|c|c|c|c|c|c|c|}
\hline \multirow{2}{*}{\multicolumn{2}{|c|}{ Group }} & \multirow[b]{2}{*}{$\mathrm{n}$} & \multicolumn{5}{|c|}{ Rough rice } & \multicolumn{5}{|c|}{ Brown rice } \\
\hline & & & $\begin{array}{c}\mathrm{GL}^{\mathrm{Z}} \\
(\mathrm{mm})\end{array}$ & $\begin{array}{c}\text { GW } \\
(\mathrm{mm})\end{array}$ & $\begin{array}{c}\text { GT } \\
(\mathrm{mm})\end{array}$ & RLW & $\begin{array}{c}\text { TGW } \\
(\mathrm{g})\end{array}$ & $\begin{array}{c}\mathrm{GL} \\
(\mathrm{mm})\end{array}$ & $\begin{array}{c}\mathrm{GW} \\
(\mathrm{mm})\end{array}$ & $\begin{array}{c}\text { GT } \\
(\mathrm{mm})\end{array}$ & RLW & $\begin{array}{c}\text { TGW } \\
\text { (g) }\end{array}$ \\
\hline \multirow{5}{*}{ A } & A1 & 6 & $10.43 b^{y}$ & $4.19 \mathrm{~cd}$ & $2.57 b c$ & $2.49 b c$ & $47.1 \mathrm{~b}$ & $7.64 b$ & 3.42 bcde & 2.31abcd & $2.24 b c$ & $39.8 b$ \\
\hline & $\mathrm{A} 2$ & 10 & $9.49 \mathrm{c}$ & $3.62 \mathrm{ef}$ & $2.37 \mathrm{def}$ & $2.63 b$ & $37.7 \mathrm{de}$ & $7.04 \mathrm{c}$ & 3.09fgh & $2.14 \mathrm{cdef}$ & $2.29 b$ & $32.9 \mathrm{de}$ \\
\hline & A3 & 8 & $9.53 c$ & $4.53 \mathrm{bc}$ & $2.70 \mathrm{~b}$ & $2.12 \mathrm{efg}$ & $45.2 \mathrm{bc}$ & $6.81 \mathrm{~cd}$ & $3.60 \mathrm{ab}$ & $2.41 \mathrm{a}$ & 1.90def & $37.5 b c$ \\
\hline & Mean & 24 & $9.74 \mathrm{~B}^{\mathrm{x}}$ & $4.07 \mathrm{~B}$ & $2.53 \mathrm{~B}$ & $2.43 \mathrm{~B}$ & $42.6 \mathrm{~B}$ & $7.12 \mathrm{~B}$ & $3.34 \mathrm{~A}$ & $2.27 \mathrm{AB}$ & $2.15 \mathrm{BC}$ & $36.1 \mathrm{~B}$ \\
\hline & C.V. $(\%)$ & 24 & 4.7 & 11.6 & 7.0 & 10.9 & 11.6 & 5.5 & 8.6 & 6.5 & 10.4 & 9.6 \\
\hline \multirow{8}{*}{ B } & $\mathrm{B} 1$ & 6 & $8.88 \mathrm{~d}$ & $3.87 \mathrm{de}$ & $2.37 \mathrm{ef}$ & $2.30 \mathrm{cde}$ & $35.2 \mathrm{efg}$ & 6.39de & $3.25 \mathrm{cdef}$ & $2.18 \mathrm{bcdef}$ & $1.97 \mathrm{de}$ & $30.6 \mathrm{def}$ \\
\hline & B2 & 13 & $8.87 \mathrm{~d}$ & $4.18 \mathrm{~cd}$ & $2.56 \mathrm{bcd}$ & $2.13 \mathrm{defg}$ & $39.7 \mathrm{de}$ & $6.32 \mathrm{ef}$ & 3.49abcd & $2.31 \mathrm{abc}$ & $1.81 \mathrm{efg}$ & $33.1 \mathrm{de}$ \\
\hline & B3 & 7 & $8.31 \mathrm{e}$ & $4.23 \mathrm{bcd}$ & $2.54 \mathrm{bcde}$ & $1.97 \mathrm{fg}$ & $37.1 \mathrm{de}$ & 5.96fgh & $3.57 \mathrm{ab}$ & $2.35 \mathrm{ab}$ & $1.67 \mathrm{gh}$ & $31.5 \mathrm{de}$ \\
\hline & B4 & 4 & $8.79 \mathrm{~d}$ & $4.58 \mathrm{~b}$ & $2.70 b$ & $1.93 \mathrm{~g}$ & $41.5 \mathrm{~cd}$ & $6.15 \mathrm{efg}$ & $3.72 \mathrm{a}$ & $2.41 \mathrm{a}$ & $1.66 \mathrm{gh}$ & $34.1 \mathrm{~cd}$ \\
\hline & B5 & 4 & $9.38 \mathrm{c}$ & $4.24 \mathrm{bcd}$ & $2.51 \mathrm{bcde}$ & $2.22 \mathrm{cdef}$ & $40.9 \mathrm{~d}$ & $6.81 \mathrm{~cd}$ & $3.51 \mathrm{abc}$ & $2.22 \mathrm{bcde}$ & $1.95 \mathrm{de}$ & $34.0 \mathrm{~cd}$ \\
\hline & B6 & 4 & $9.30 \mathrm{c}$ & $3.94 \mathrm{de}$ & $2.40 \mathrm{cdef}$ & $2.63 b$ & $37.5 \mathrm{de}$ & $6.77 \mathrm{~cd}$ & $3.23 \mathrm{def}$ & $2.17 \mathrm{bcdef}$ & $2.10 \mathrm{bcd}$ & $31.5 \mathrm{de}$ \\
\hline & Mean & 38 & $8.86 \mathrm{C}$ & $4.16 \mathrm{~B}$ & $2.52 \mathrm{~B}$ & $2.17 \mathrm{~B}$ & $38.6 \mathrm{BC}$ & $6.34 \mathrm{C}$ & $3.47 \mathrm{~A}$ & $2.28 \mathrm{AB}$ & $1.84 \mathrm{CD}$ & $32.4 \mathrm{BC}$ \\
\hline & C.V.(\%) & 38 & 4.8 & 6.3 & 5.6 & 12.5 & 8.5 & 6.0 & 5.5 & 5.9 & 9.8 & 7.0 \\
\hline \multirow{9}{*}{$\mathrm{C}$} & $\mathrm{C} 1$ & 9 & $8.02 \mathrm{ef}$ & $4.17 \mathrm{~cd}$ & $2.58 b c$ & $1.93 \mathrm{~g}$ & $35.5 \mathrm{ef}$ & 5.64hij & 3.49abcd & $2.35 \mathrm{ab}$ & $1.62 \mathrm{gh}$ & $29.5 \mathrm{ef}$ \\
\hline & $\mathrm{C} 2$ & 1 & $7.49 \mathrm{~g}$ & $3.94 \mathrm{de}$ & $2.36 \mathrm{ef}$ & $1.90 \mathrm{~g}$ & $29.9 \mathrm{~h}$ & $5.24 \mathrm{jk}$ & 3.34bcdef & $2.13 \mathrm{cdef}$ & $1.57 \mathrm{~h}$ & $24.9 \mathrm{ghi}$ \\
\hline & $\mathrm{C} 3$ & 5 & $7.58 \mathrm{~g}$ & $3.64 \mathrm{ef}$ & $2.36 \mathrm{ef}$ & $2.09 \mathrm{efg}$ & $30.1 \mathrm{~h}$ & $5.46 \mathrm{ijk}$ & $3.20 \mathrm{efg}$ & $2.12 \mathrm{def}$ & $1.71 \mathrm{fgh}$ & 25.0ghi \\
\hline & $\mathrm{C} 4$ & 5 & $7.25 \mathrm{~g}$ & $3.66 \mathrm{ef}$ & $2.34 \mathrm{ef}$ & $1.99 \mathrm{fg}$ & 28.0hi & $5.18 \mathrm{k}$ & $3.08 \mathrm{fgh}$ & $2.13 \mathrm{cdef}$ & $1.69 \mathrm{gh}$ & $22.6 \mathrm{hi}$ \\
\hline & $\mathrm{C} 5$ & 6 & $8.06 \mathrm{ef}$ & $3.35 \mathrm{f}$ & $2.26 \mathrm{fg}$ & $2.41 \mathrm{bcd}$ & 28.9hi & 5.80ghi & $2.83 \mathrm{hi}$ & $2.03 \mathrm{ef}$ & $2.05 \mathrm{~cd}$ & 24.0hi \\
\hline & C6 & 2 & $7.66 f g$ & $3.50 \mathrm{f}$ & $2.24 \mathrm{gf}$ & $2.22 \mathrm{cdef}$ & $24.9 \mathrm{i}$ & $5.49 \mathrm{ijk}$ & 2.89hi & $1.99 \mathrm{f}$ & $1.93 \mathrm{de}$ & $21.8 \mathrm{i}$ \\
\hline & $\mathrm{C} 7$ & 3 & $8.37 \mathrm{e}$ & $3.48 \mathrm{f}$ & $2.29 \mathrm{fg}$ & $2.42 b c$ & $31.1 \mathrm{gh}$ & $6.20 \mathrm{efg}$ & $2.96 \mathrm{gh}$ & $2.07 \mathrm{ef}$ & $2.11 \mathrm{bcd}$ & $25.9 \mathrm{gh}$ \\
\hline & Mean & 31 & $7.83 \mathrm{D}$ & $3.73 \mathrm{~B}$ & 2.39BC & $2.12 \mathrm{~B}$ & $30.8 \mathrm{D}$ & $5.60 \mathrm{D}$ & $3.16 \mathrm{~A}$ & $2.16 \mathrm{CB}$ & $1.79 \mathrm{D}$ & $25.6 \mathrm{D}$ \\
\hline & C.V.(\%) & 31 & 5.3 & 9.7 & 6.7 & 10.6 & 13.1 & 6.2 & 9.1 & 7.6 & 12.1 & 13.6 \\
\hline $\mathrm{D}$ & $\mathrm{D}$ & 1 & $11.52 \mathrm{aA}$ & $5.41 \mathrm{aA}$ & $2.97 \mathrm{aA}$ & $2.13 \mathrm{defgB}$ & $56.6 \mathrm{aA}$ & $8.17 \mathrm{aA}$ & $3.57 \mathrm{abA}$ & $2.45 \mathrm{aA}$ & $2.29 \mathrm{bB}$ & $48.1 \mathrm{aA}$ \\
\hline$E$ & $E$ & 2 & $9.65 \mathrm{cB}$ & $3.00 \mathrm{gC}$ & $2.14 \mathrm{gC}$ & $3.22 \mathrm{aA}$ & $32.4 \mathrm{fghCD}$ & $7.52 \mathrm{bB}$ & $2.69 \mathrm{iB}$ & $1.99 \mathrm{fC}$ & $2.81 \mathrm{aA}$ & $27.9 \mathrm{fgCD}$ \\
\hline \multirow{2}{*}{ Total } & Mean & 96 & 8.79 & 4.00 & 2.47 & 2.24 & 37.1 & 6.34 & 3.32 & 2.23 & 1.93 & 31.2 \\
\hline & C.V.(\%) & 96 & 10.2 & 11.2 & 7.3 & 13.9 & 17.2 & 11.5 & 8.9 & 7.2 & 14.5 & 17.3 \\
\hline
\end{tabular}

${ }^{\mathrm{z}} \mathrm{GL}$ : grain length, GW: grain width, GT: grain thickness, RLW: ratio of length to width, TGW: 1000-grain weight

${ }^{\mathrm{y}}$ Means with the same letters in a column are not significantly different at $p<0.05$ (ANOVA followed by DMRT)

${ }^{\mathrm{x}}$ Capital letters indicate statistic difference among main groups defined by culstering analysis

Table 6. Eigenvectors for the principal component analysis of the traits and correlation coefficient between the traits and principal components.

\begin{tabular}{|c|c|c|c|c|c|c|}
\hline \multirow{2}{*}{ Trait } & \multicolumn{3}{|c|}{ Eigenvector } & \multicolumn{3}{|c|}{ Correlation coefficient } \\
\hline & $\operatorname{Prin}^{\mathrm{y}}$ & Prin2 & Prin3 & Prin1 & Prin2 & Prin3 \\
\hline $\mathrm{GL}^{\mathrm{z}}$ & 0.232 & 0.425 & -0.171 & $0.551^{* * x}$ & $0.822^{* *}$ & $-0.089^{\mathrm{ns}}$ \\
\hline GW & 0.392 & -0.109 & -0.411 & $0.931^{* *}$ & $-0.212^{*}$ & $-0.213^{*}$ \\
\hline GT & 0.393 & -0.112 & 0.422 & $0.933^{* *}$ & $-0.218^{*}$ & $0.218^{*}$ \\
\hline RLW & -0.165 & 0.447 & 0.280 & $-0.391^{* *}$ & $0.865^{* *}$ & $0.145^{\mathrm{ns}}$ \\
\hline TGW & 0.386 & 0.189 & -0.028 & $0.918^{* *}$ & $0.365^{* *}$ & $-0.014^{\mathrm{ns}}$ \\
\hline $\mathrm{GLb}^{\mathrm{w}}$ & 0.170 & 0.466 & -0.180 & $0.405^{* *}$ & $0.902^{* *}$ & $-0.093^{\mathrm{ns}}$ \\
\hline $\mathrm{GWb}$ & 0.375 & -0.179 & -0.320 & $0.890^{* *}$ & $-0.347^{* *}$ & $-0.166^{\mathrm{ns}}$ \\
\hline $\mathrm{GTb}$ & 0.376 & -0.143 & 0.627 & $0.894^{* *}$ & $-0.277^{* *}$ & $0.325^{* *}$ \\
\hline RLWb & -0.106 & 0.491 & 0.122 & $-0.253^{*}$ & $0.950^{* *}$ & $0.063^{\mathrm{ns}}$ \\
\hline TGWb & 0.373 & 0.223 & 0.052 & $0.887^{* *}$ & $0.431^{* *}$ & $0.027^{\mathrm{ns}}$ \\
\hline Eigen value & 5.64 & 3.75 & 0.27 & & & \\
\hline Contribution $(\%)$ & 56.4 & 37.5 & 2.7 & & & \\
\hline Cumulative contribution (\%) & 56.4 & 93.9 & 96.6 & & & \\
\hline
\end{tabular}

${ }^{\mathrm{z}} \mathrm{GL}$ : grain length, GW: grain width, GT: grain thickness, RLW: ratio of length to width, TGW: 1000-grain weight

${ }^{\mathrm{y}}$ Prin1, Prin2, and Prin3 indicate the first, second, and third component, respectively

${ }_{\mathrm{ns}}, *$, and $* *$ mean no significant, significant at $p<0.05$, and $p<0.01$, respectively

${ }^{\mathrm{w}} \mathrm{b}$ means brown rice 

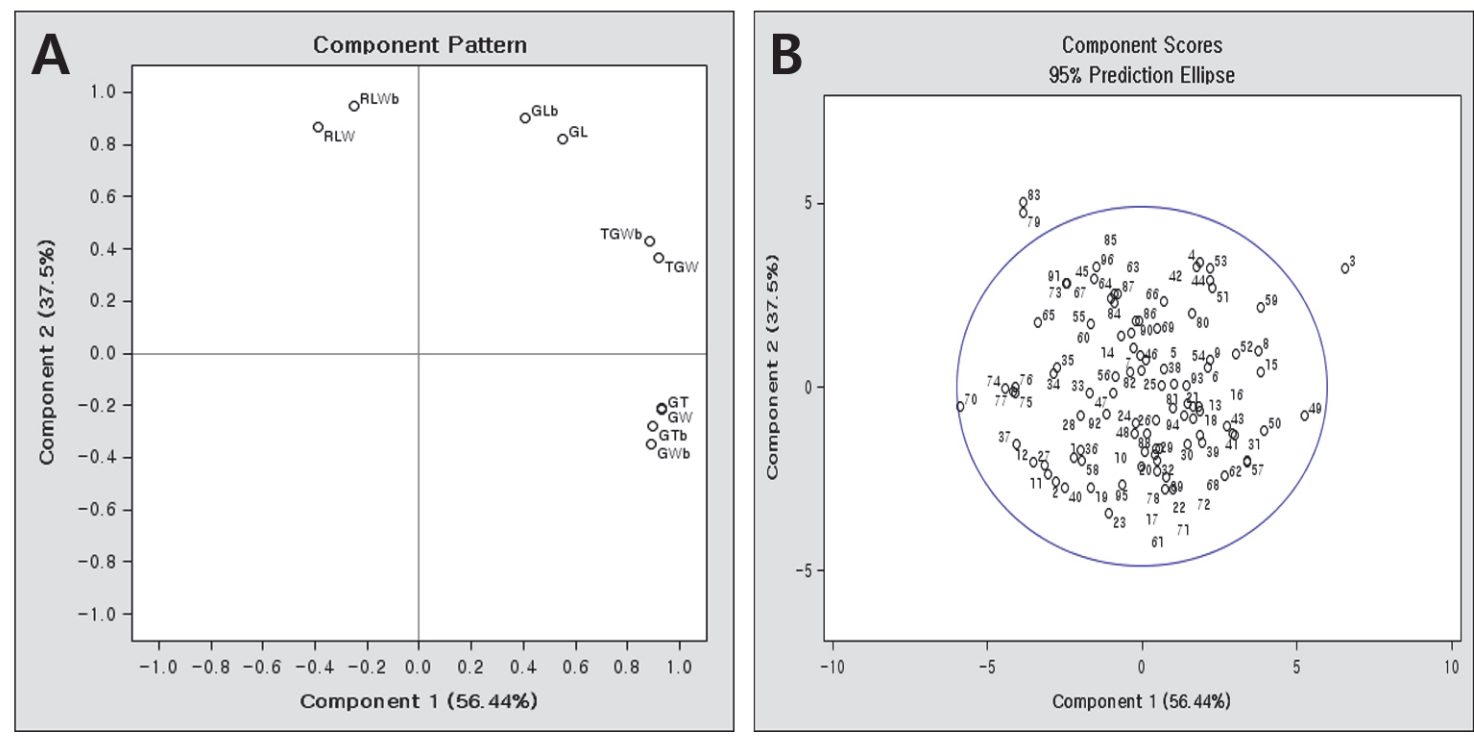

Fig 3. Relationship among the traits (A) and lines (B) in the principal component analysis (PCA) diagram composed of component 1 and 2. GL, GW, GT, RLW, and TGW mean grain length, grain width, grain thickness, ration of length to width, and 1000 -grain weight of rough rice, respectively. GLb, GWb, GTb, RLWb, and TGWb mean grain length, grain width, grain thickness, ration of length to width, and 1000-grain weight of brown rice, respectively.

Table 7. Comparison of grain-related traits of brown rice between the breeding materials and Korean rice cultivars.

\begin{tabular}{|c|c|c|c|c|c|c|}
\hline Group & $\mathrm{n}$ & $\begin{array}{c}\mathrm{GL}^{\mathrm{z}} \\
(\mathrm{mm})\end{array}$ & $\begin{array}{l}\text { GW } \\
(\mathrm{mm})\end{array}$ & $\begin{array}{c}\text { GT } \\
(\mathrm{mm})\end{array}$ & RLW & $\begin{array}{c}\text { TGW } \\
(\mathrm{g})\end{array}$ \\
\hline Deuraechan & 1 & 5.44 & 3.19 & 2.12 & 1.71 & 24.7 \\
\hline Boramchan & 1 & 5.09 & 3.06 & 2.13 & 1.67 & 22.9 \\
\hline Jizi1560 & 1 & 8.17 & 3.57 & 2.45 & 2.29 & 48.1 \\
\hline Jizi1581 & 1 & 7.89 & 3.43 & 2.29 & 2.30 & 38.0 \\
\hline Daeripbyeo 1 & 1 & 6.36 & 3.48 & 2.25 & 1.83 & 34.6 \\
\hline DH lines & 91 & $\begin{array}{c}6.34 \pm 0.68 \mathrm{a}^{\mathrm{y}} \\
(5.09-7.69)\end{array}$ & $\begin{array}{l}3.32 \pm 0.30 \mathrm{a} \\
(2.66-3.91)\end{array}$ & $\begin{array}{l}2.23 \pm 0.16 \mathrm{a} \\
(1.83-2.63)\end{array}$ & $\begin{array}{l}1.93 \pm 0.28 \mathrm{c} \\
(1.53-2.83)\end{array}$ & $\begin{array}{c}31.1 \pm 5.1 \mathrm{a} \\
(18.6-41.5)\end{array}$ \\
\hline japonica & 264 & $\begin{array}{l}5.03 \pm 0.23 \mathrm{~d}^{\mathrm{x}} \\
(4.29-6.20)\end{array}$ & $\begin{array}{l}2.82 \pm 0.11 \mathrm{~b} \\
(2.51-3.20)\end{array}$ & $\begin{array}{l}1.94 \pm 0.13 b \\
(1.23-2.30)\end{array}$ & $\begin{array}{l}1.79 \pm 0.09 \mathrm{~d} \\
(1.55-2.02)\end{array}$ & $\begin{array}{c}22.0 \pm 2.0 \mathrm{~b} \\
(14.1-34.8)\end{array}$ \\
\hline black rice & 13 & $\begin{array}{l}5.34 \pm 0.63 c \\
(3.76-5.96)\end{array}$ & $\begin{array}{l}2.57 \pm 0.12 \mathrm{c} \\
(2.33-2.75)\end{array}$ & $\begin{array}{l}1.78 \pm 0.11 \mathrm{c} \\
(1.57-1.97)\end{array}$ & $\begin{array}{l}2.08 \pm 0.25 b \\
(1.46-2.36)\end{array}$ & $\begin{array}{c}19.5 \pm 2.9 \mathrm{c} \\
(14.8-23.5)\end{array}$ \\
\hline Tongil-type & 32 & $\begin{array}{c}5.69 \pm 0.30 \mathrm{~b} \\
(5.09-6.49)\end{array}$ & $\begin{array}{l}2.57 \pm 0.13 \mathrm{c} \\
(2.30-2.91)\end{array}$ & $\begin{array}{l}1.83 \pm 0.13 \mathrm{c} \\
(1.60-2.14)\end{array}$ & $\begin{array}{l}2.22 \pm 0.19 \mathrm{a} \\
(1.79-2.65)\end{array}$ & $\begin{array}{c}22.5 \pm 2.1 b \\
(18.9-28.2)\end{array}$ \\
\hline
\end{tabular}

${ }^{\mathrm{z}} \mathrm{GL}$ : grain length, GW: grain width, GT: grain thickness, RLW: ratio of length to width, TGW: 1000-grain weight

${ }^{\mathrm{y}}$ Means with the same letters in a column are not significantly different at $p<0.05$ (ANOVA followed by DMRT)

${ }^{\mathrm{x}}$ The data of japonica, black rice, and Tongil-type cultivars were used the value on registration of national variety and in the website of 'Nongsaro' (http://www.nongsaro.go.kr/)

구조적 관계를 보면 주성분 1 을 기준으로 낟알의 두께, 너비, 천립중 및 길이가 장폭비와 다른 방향성을 나타냈으며, 주성분 2 를 기준으로는 장폭비, 낟알 길이, 천립중이 두께와 너비와 다른 방향성을 나타냈다(Fig. $3 \mathrm{~A}$ ). 공시재료들의 구조적 관계를 보면 DGS3(Jizi1560)과 DGS79및 DGS83(그룹 E에 속함)은 주성분 분포 값의 $95 \%$ 수준을 벗어난 곳에 위치함으로써 다른 공시재
료들에 비해서 입형 특성이 특이한 것으로 나타났다(Fig. 3B). 개발된 입형 다양화 육종소재의 입형 관련 형질의 다양성을 알아보기 위해 국립식량과학원에서 육성된 319개 벼 품종(자포니카 264 품종, 흑미 13, 통일형 32)의 육성당시 현미 입형 데이터와 비교 분석하였다(Table 7). 입형 다양화 육종소재는 현미 길이, 너비, 두께, 장폭비, 천립중 등 모든 형질에서 가장 넓은 범위와 가장 


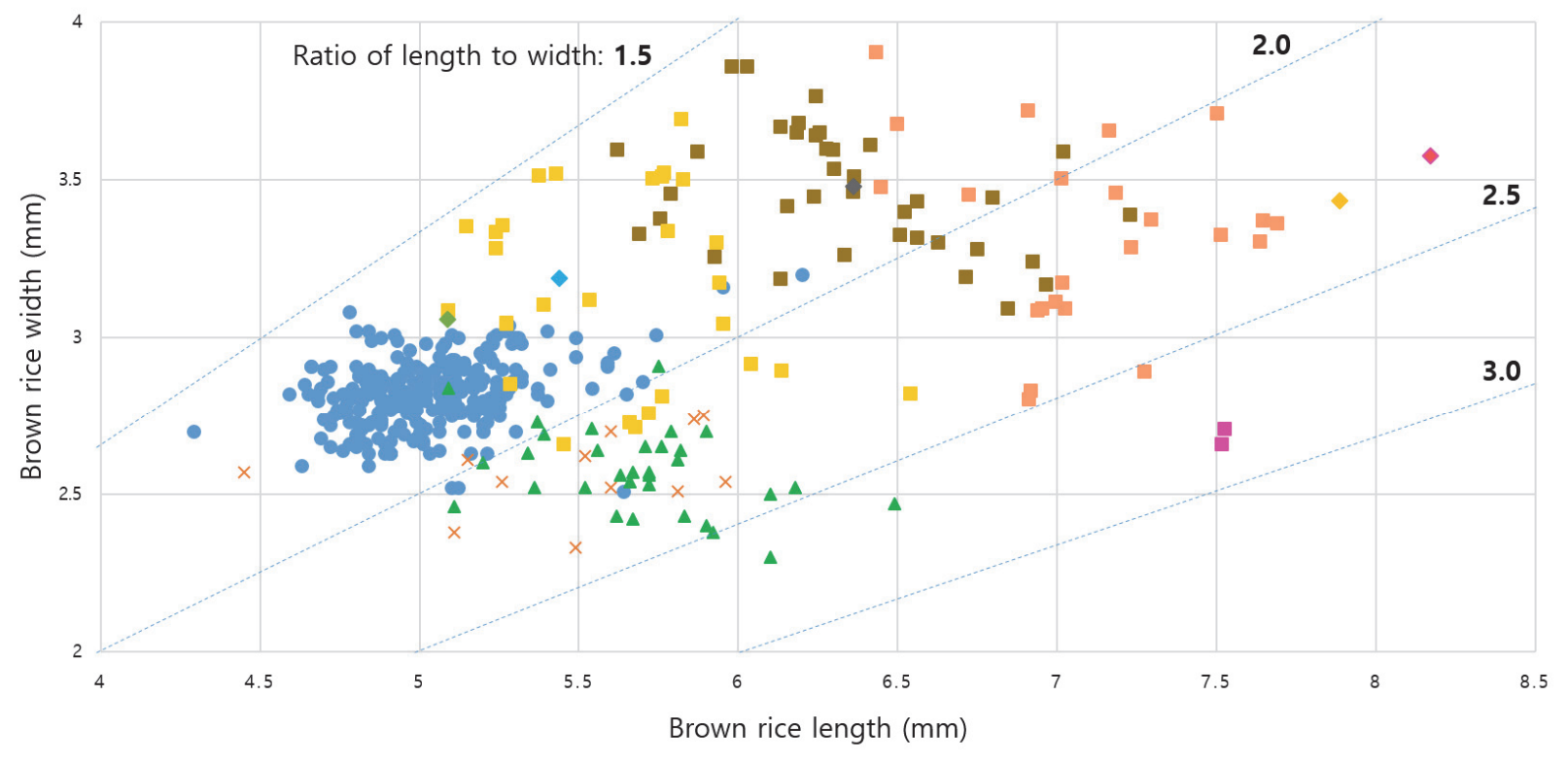

- japonica $\times$ black rice $\Delta$ Tongil-type $\square \mathrm{A}\|\mathrm{B}\| \mathrm{C} \| \mathrm{E} \bullet \mathrm{DR} \bullet \mathrm{BR} \bullet \mathrm{JZ1560}(\mathrm{D}) \diamond \mathrm{JZ1581} \bullet \mathrm{DRB} 1$

Fig. 4. Distribution of the breeding materials and Korean rice cultivars using brown rice length and width. Korean rice cultivars were classified into japonica (blue round mark, $\mathrm{n}=264$ ), black rice (brown $\mathrm{x}$-mark, $\mathrm{n}=13$ ), and Tongil-type (green triangle mark, $\mathrm{n}=32$ ).

높은 표준편차를 보였다. 또한 현미 길이와 너비를 이용한 산포도 에서 우리나라 자포니카 벼 품종들은 현미 장폭비 1.5 에서 2.0 사이의 단원형에 모든 품종이 조밀하게 모여 있는 반면 입형 다양화 육종소재는 현미 길이와 너비의 형질 값의 분포가 넓으며 단원형, 중원형, 장원형의 여러 형태에 분포하여 다양한 입형 특성을 나타내는 것으로 확인되었다(Fig. 4).

\section{입형 다양화 육종소재의 수량 관련 형질 특성}

입형 다양화 육종소재의 수량 관련 형질 값은 Table 8 와 같다. 출수는 그룹 $\mathrm{D}(92 \mathrm{DAS})$ 와 $\mathrm{A}(97 \mathrm{DAS})$ 가 상대적으로 빠르고 그 다음으로 그룹 $\mathrm{B}(103 \mathrm{DAS})$ 와 $\mathrm{C}(106 \mathrm{DAS})$ 가 출수하며 그룹 $\mathrm{E}(128 \mathrm{DAS})$ 가 가장 늦었다. 간장은 그룹 $\mathrm{E}(98 \mathrm{~cm})$ 가 가장 크고 그룹 $\mathrm{D}(92 \mathrm{~cm})$ 가 그 다음이며, 그룹 $\mathrm{A}(82 \mathrm{~cm}), \mathrm{B}(81$ $\mathrm{cm}), \mathrm{C}(81 \mathrm{~cm})$ 는 비슷한 수준으로 작았다. 수장과 수수는 통계 적으로 유의한 차이가 없었다. 수당립수는 그룹 $\mathrm{C}(125$ 개)와 $\mathrm{E}(123$ 개)가 많았으며 그 다음으로 그룹 $\mathrm{A}(103$ 개)와 $\mathrm{B}(103$ 개) 였으며 그룹 $\mathrm{D}(55$ 개 $)$ 가 가장 적었다. 등숙률은 그룹 $\mathrm{C}(73.8 \%)$, $\mathrm{E}(73.8 \%), \mathrm{B}(60.4 \%), \mathrm{A}(51.9 \%)$ 순이었으며 그룹 $\mathrm{D}$ 는 $7.1 \%$ 로 매우 낮은 등숙상태를 보였다. 20주 정조수량은 그룹 $\mathrm{C}(577$ $\mathrm{g}), \mathrm{E}(542 \mathrm{~g}), \mathrm{B}(500 \mathrm{~g}), \mathrm{A}(458 \mathrm{~g}), \mathrm{D}(362 \mathrm{~g})$ 순이었다. 입형
다양화 육종소재의 입형 및 수량 관련 형질들 간의 상관관계를 분석하였다(Table 9). 낟알의 길이는 천립중 $(r=0.801,0.741$; 정조 및 현미 $)$, 장폭비 $(0.478,0.759)$, 수장 $(0.475,0.477)$ 및 간장 $(0.237,0.289)$ 과 정의 상관을 나타냈고 등숙률(-0.508, $-0.447)$, 정조수량(-0.476, -0.420), 수당립수(-0.427, -0.345), 출수기( $-0.255,-0.220)$ 와는 부의 상관을 나타냈다. 낟알의 너비 는 두께 $(r=0.887,0.850$; 정조 및 현미 $)$ 와 천립중 $(0.768,0.639)$ 과 정의 상관을 나타냈고 장폭비(-0.576, -0.591$)$, 등숙률 (-0.561, -0.398), 정조수량(-0.491, -0.410), 수당립수(-0.463, $-0.381)$, 출수기 $(-0.310,-0.208)$, 수수 $(-0.230,-0.269)$ 와는 부의 상관을 나타냈다. 낟알의 두께는 천립중 $(r=0.770,0.680$; 정조 및 현미)과 정의 상관을 나타냈고 수당립수 $(-0.431,-0.359)$, 정조수량(-0.427, -0.367), 등숙률(-0.417, -0.375), 수수(-0.249, $-0.285)$ 와는 부의 상관을 나타냈다. 장폭비는 수장 $(r=0.292$, 0.355 ; 정조 및 현미 $)$ 과 간장 $(0.255,0.324)$ 과 정의 상관관계를 나타냈다. 천립중은 수장 $(r=0.292,0.366$; 정조 및 현미)과 정의 상관 관계를 나타냈고 수당립수(-0.576, -0.506), 정조수량 $(-0.554,-0.529)$, 등숙률(-0.498, -0.522), 출수기(-0.270, $-0.276)$, 수수 $(-0.213,-0.243)$ 와는 부의 상관을 나타냈다. 출수 기는 간장 $(r=0.525)$, 등숙률( $(0.440)$, 정조수량 $(0.434)$, 수당립수 
Table 8. Yield-related traits of the breeding materials.

\begin{tabular}{|c|c|c|c|c|c|c|c|c|c|}
\hline & Group & $\mathrm{n}$ & $\begin{array}{c}\mathrm{HD}^{\mathrm{z}} \\
(\mathrm{DAS})\end{array}$ & $\begin{array}{c}\mathrm{CL} \\
(\mathrm{cm})\end{array}$ & $\begin{array}{c}\mathrm{PL} \\
(\mathrm{cm})\end{array}$ & PN & NS & $\begin{array}{c}\text { RRG } \\
(\%)\end{array}$ & $\begin{array}{c}\text { Yield } \\
(\mathrm{g})\end{array}$ \\
\hline \multirow{5}{*}{ A } & A1 & 6 & $95 b c^{y}$ & $80 \mathrm{ab}$ & $24 a b c$ & $11 \mathrm{abc}$ & $68 \mathrm{de}$ & 66.6abcd & $468 \mathrm{cdef}$ \\
\hline & $\mathrm{A} 2$ & 10 & $94 b c$ & $80 \mathrm{ab}$ & $26 a$ & $9 \mathrm{bc}$ & $136 \mathrm{ab}$ & $52.7 \mathrm{de}$ & 494bcdef \\
\hline & A3 & 8 & $102 b c$ & $84 a b$ & $23 \mathrm{abc}$ & $9 \mathrm{abc}$ & $88 \mathrm{cde}$ & $39.9 \mathrm{e}$ & $405 \mathrm{ef}$ \\
\hline & Mean & 24 & $97 \mathrm{~B}^{\mathrm{x}}$ & $82 \mathrm{~B}$ & $24 \mathrm{~A}$ & $9 \mathrm{~A}$ & $103 \mathrm{AB}$ & $51.9 \mathrm{~A}$ & $458 \mathrm{AB}$ \\
\hline & C.V.(\%) & 24 & 10.5 & 13.9 & 8.2 & 19.6 & 38.2 & 36.2 & 16.7 \\
\hline \multirow{8}{*}{ B } & B1 & 6 & $97 \mathrm{bc}$ & $79 b$ & $24 a b c$ & $11 \mathrm{abc}$ & 95 bcde & $55.7 \mathrm{cde}$ & 483bcdef \\
\hline & B2 & 13 & $102 b c$ & $80 \mathrm{ab}$ & $23 a b c$ & $10 \mathrm{abc}$ & $94 \mathrm{bcde}$ & $68.2 \mathrm{abcd}$ & 511abcdef \\
\hline & B3 & 7 & $106 b c$ & $81 \mathrm{ab}$ & $23 \mathrm{abc}$ & $8 \mathrm{c}$ & $125 \mathrm{abc}$ & 59.8 bcde & 527abcde \\
\hline & B4 & 4 & $107 b c$ & $73 b$ & $22 b c$ & $10 \mathrm{abc}$ & $93 \mathrm{bcde}$ & $53.4 \mathrm{de}$ & $453 \mathrm{def}$ \\
\hline & B5 & 4 & $109 \mathrm{abc}$ & $90 \mathrm{ab}$ & $24 a b c$ & $8 \mathrm{c}$ & $112 \mathrm{abc}$ & $54.1 \mathrm{de}$ & 446def \\
\hline & B6 & 4 & $98 b c$ & $82 \mathrm{ab}$ & $25 \mathrm{ab}$ & $11 \mathrm{abc}$ & 105abcd & $56.5 \mathrm{cde}$ & 544abcde \\
\hline & Mean & 38 & $103 \mathrm{~B}$ & $81 \mathrm{~B}$ & $23 \mathrm{~A}$ & $10 \mathrm{~A}$ & $103 \mathrm{AB}$ & $60.4 \mathrm{~A}$ & $500 \mathrm{AB}$ \\
\hline & C.V.(\%) & 38 & 13.2 & 14.4 & 8.3 & 19.5 & 24.2 & 26.2 & 17.9 \\
\hline \multirow{9}{*}{$\mathrm{C}$} & $\mathrm{C} 1$ & 9 & $99 \mathrm{bc}$ & $75 b$ & $23 a b c$ & $10 \mathrm{abc}$ & $118 \mathrm{abc}$ & 64.7abcde & 523abcdef \\
\hline & $\mathrm{C} 2$ & 1 & 109abc & $83 a b$ & $21 \mathrm{c}$ & $12 \mathrm{a}$ & $123 \mathrm{abc}$ & 84.6ab & 632abc \\
\hline & $\mathrm{C} 3$ & 5 & $109 \mathrm{abc}$ & $76 b$ & $22 b c$ & $12 \mathrm{ab}$ & $118 \mathrm{abc}$ & 77.5abcd & 554abcde \\
\hline & $\mathrm{C} 4$ & 5 & $104 b c$ & $76 b$ & $21 \mathrm{c}$ & $12 \mathrm{ab}$ & $135 \mathrm{ab}$ & $81.5 \mathrm{abc}$ & $641 \mathrm{ab}$ \\
\hline & $\mathrm{C} 5$ & 6 & $115 \mathrm{ab}$ & $83 a b$ & $21 \mathrm{c}$ & $10 \mathrm{abc}$ & $125 \mathrm{abc}$ & $86.9 \mathrm{a}$ & 596abcd \\
\hline & C6 & 2 & $104 b c$ & $73 b$ & $22 b c$ & $11 \mathrm{abc}$ & $150 \mathrm{a}$ & 69.1 abcd & $666 a$ \\
\hline & $\mathrm{C} 7$ & 3 & $110 \mathrm{abc}$ & $81 \mathrm{ab}$ & $23 \mathrm{abc}$ & $10 \mathrm{abc}$ & $122 \mathrm{abc}$ & 78.8abcd & 556abcde \\
\hline & Mean & 31 & 106B & $78 \mathrm{~B}$ & $22 \mathrm{~A}$ & $11 \mathrm{~A}$ & $125 \mathrm{~A}$ & $76.1 \mathrm{~A}$ & $577 \mathrm{~A}$ \\
\hline & C.V.(\%) & 31 & 10.3 & 8.2 & 8.1 & 18.0 & 18.5 & 15.4 & 17.8 \\
\hline $\mathrm{D}$ & $\mathrm{D}$ & 1 & $92 \mathrm{cB}$ & 91abAB & 24abcA & $10 \mathrm{abcA}$ & $55 \mathrm{eB}$ & $7.1 \mathrm{fB}$ & $362 \mathrm{fB}$ \\
\hline$E$ & $E$ & 2 & $128 \mathrm{aA}$ & $98 \mathrm{aA}$ & 24abcA & $10 \mathrm{abcA}$ & 123abcA & 73.8abcdA & 542abcdeA \\
\hline \multirow{2}{*}{ Total } & Mean & 96 & 103 & 80 & 23 & 10 & 110 & 63.0 & 513 \\
\hline & C.V.(\%) & 96 & 12.4 & 12.9 & 8.8 & 18.4 & 27.7 & 29.7 & 19.9 \\
\hline
\end{tabular}

${ }^{\mathrm{z}} \mathrm{HD}$ : heading date, DAS: days after seeding, CL: culm length, PL: panicle length, PN: number of panicles per hill, NS: number of spikelets per panicle, RRG: ratio of ripened grain

${ }^{\mathrm{y}}$ Means with the same letters in a column are not significantly different at $p<0.05$ (ANOVA followed by DMRT)

${ }^{\mathrm{x}}$ Capital letters indicate statistic difference among main groups defined by culstering analysis

Table 9. Correlation coefficient among grain and yield-related traits in the breeding materials.

\begin{tabular}{|c|c|c|c|c|c|c|c|c|c|c|c|c|}
\hline Trait $^{\mathrm{z}}$ & $\begin{array}{c}\mathrm{GL}^{\mathrm{y}} \\
(\mathrm{x} 1,6)\end{array}$ & $\begin{array}{c}\text { GW } \\
(x 2,7)\end{array}$ & $\begin{array}{c}\text { GT } \\
(\times 3,8)\end{array}$ & $\begin{array}{c}\text { RLW } \\
(\mathrm{x} 4,9)\end{array}$ & $\begin{array}{c}\text { TGW } \\
(\times 5,10)\end{array}$ & $\begin{array}{l}\text { HD } \\
(\mathrm{x} 11)\end{array}$ & $\begin{array}{c}\mathrm{CL} \\
(\mathrm{x} 12) \\
\end{array}$ & $\begin{array}{c}\mathrm{PL} \\
(\mathrm{x} 13)\end{array}$ & $\begin{array}{c}\mathrm{PN} \\
(\mathrm{x} 14)\end{array}$ & $\begin{array}{c}\text { NS } \\
(\times 15)\end{array}$ & $\begin{array}{l}\text { RRG } \\
(\mathrm{x} 16)\end{array}$ & $\begin{array}{l}\text { Yield } \\
(\mathrm{x} 17) \\
\end{array}$ \\
\hline $\mathrm{x} 1,6$ & & $0.364^{* *}$ & $0.322^{* *}$ & $0.478^{* *}$ & $0.801^{* *}$ & $-0.255^{*}$ & $0.237^{*}$ & $0.475^{* *}$ & $-0.168^{\mathrm{ns}}$ & $-0.427^{* *}$ & $-0.508^{* *}$ & $-0.476^{* *}$ \\
\hline$x 2,7$ & $0.066^{\mathrm{nsx}}$ & & $0.887^{* *}$ & $-0.576^{* *}$ & $0.768^{* *}$ & $-0.310^{* *}$ & $-0.127^{\mathrm{ns}}$ & $0.043^{\mathrm{ns}}$ & $-0.230^{*}$ & $-0.463^{* *}$ & $-0.561^{* *}$ & $-0.491^{* *}$ \\
\hline$x 3,8$ & $0.088^{\mathrm{ns}}$ & $0.850^{* *}$ & & $-0.534^{* *}$ & $0.770^{* *}$ & $-0.190^{\mathrm{ns}}$ & $-0.068^{\mathrm{ns}}$ & $0.038^{\mathrm{ns}}$ & $-0.249^{*}$ & $-0.431^{* *}$ & $-0.417^{* *}$ & $-0.427^{* *}$ \\
\hline$x 4,8$ & $0.759^{* *}$ & $-0.591^{* *}$ & $-0.467^{* *}$ & & $-0.043^{\mathrm{ns}}$ & $0.075^{\mathrm{ns}}$ & $0.255^{*}$ & $0.396^{* *}$ & $0.037^{\mathrm{ns}}$ & $0.048^{\mathrm{ns}}$ & $0.080^{\mathrm{ns}}$ & $0.012^{\mathrm{ns}}$ \\
\hline$x 5,10$ & $0.741^{* *}$ & $0.639^{* *}$ & $0.680^{* *}$ & $0.177^{\text {ns }}$ & & $-0.270^{* *}$ & $0.103^{\mathrm{ns}}$ & $0.292^{* *}$ & $-0.213^{*}$ & $-0.576^{* *}$ & $-0.498^{* *}$ & $-0.554^{* *}$ \\
\hline x11 & $-0.220^{*}$ & $-0.208^{*}$ & $-0.166^{\mathrm{ns}}$ & $-0.024^{\mathrm{ns}}$ & -0.27 & & $0.525^{* *}$ & $-0.257^{*}$ & $-0.007^{\mathrm{ns}}$ & $0.290^{* *}$ & $0.440^{* *}$ & $0.434^{* *}$ \\
\hline $\mathrm{x} 12$ & $0.289^{* *}$ & $-0.133^{\mathrm{ns}}$ & $-0.090^{\mathrm{ns}}$ & $0.324^{* *}$ & 0.106 & 0.525 & & & $-0.192^{\mathrm{ns}}$ & & $0.115^{\mathrm{ns}}$ & $0.209^{*}$ \\
\hline $\mathrm{x} 13$ & $0.477^{* *}$ & $0.057^{\mathrm{ns}}$ & $0.033^{\mathrm{ns}}$ & $0.355^{* *}$ & $0.366^{* *}$ & $-0.257^{*}$ & 0.141 & & $-0.425^{* *}$ & & $-0.324^{* *}$ & $-0.274^{* *}$ \\
\hline $\mathrm{x} 14$ & $-0.150^{\mathrm{ns}}$ & $-0.269^{* *}$ & $-0.285^{* *}$ & $0.033^{\text {ns }}$ & $-0.243^{*}$ & $-0.007^{\mathrm{ns}}$ & $-0.192^{\mathrm{ns}}$ & $-0.425^{* *}$ & & $-0.451^{* *}$ & $0.462^{* *}$ & $0.240^{*}$ \\
\hline $\mathrm{x} 15$ & $-0.345^{* *}$ & $-0.381^{* *}$ & $-0.359^{* *}$ & $-0.022^{\mathrm{ns}}$ & $-0.506^{* *}$ & $0.290^{* *}$ & $0.108^{\mathrm{ns}}$ & $0.132^{\mathrm{ns}}$ & $-0.451^{* *}$ & & $0.038^{\mathrm{ns}}$ & $0.507^{* *}$ \\
\hline $\mathrm{x} 16$ & $-0.447^{* *}$ & $-0.398^{* *}$ & $-0.375^{* *}$ & $-0.100^{\mathrm{ns}}$ & $-0.522^{* *}$ & $0.440^{* *}$ & $0.115^{\mathrm{ns}}$ & $-0.324^{* *}$ & $0.462^{* *}$ & 0.03 & & $0.575^{* *}$ \\
\hline $\mathrm{x} 17$ & $0.420^{* *}$ & $-0.410^{* *}$ & $-0.367^{* *}$ & $-0.081^{\mathrm{ns}}$ & $-0.529^{* *}$ & $0.434^{* *}$ & $0.209^{*}$ & $-0.274^{* *}$ & $0.240^{*}$ & $0.507^{* *}$ & $0.575^{* *}$ & \\
\hline
\end{tabular}

${ }^{\mathrm{z}}$ Upper and lower diagonal indicate the value of rough and brown rice, respectively

${ }^{y}$ GL: grain length, GW: grain width, GT: grain thickness, RLW: ratio of length to width, TGW: 1000-grain weight, HD: heading date, CL: culm length, PL: panicle length, PN: number of panicles per hill, NS: number of spikelets per panicle, RRG: ratio of ripened grain

$\mathrm{x}_{\mathrm{ns}}{ }^{*}$, and $* *$ mean no significant, significant at $p<0.05$, and $p<0.01$, respectively 


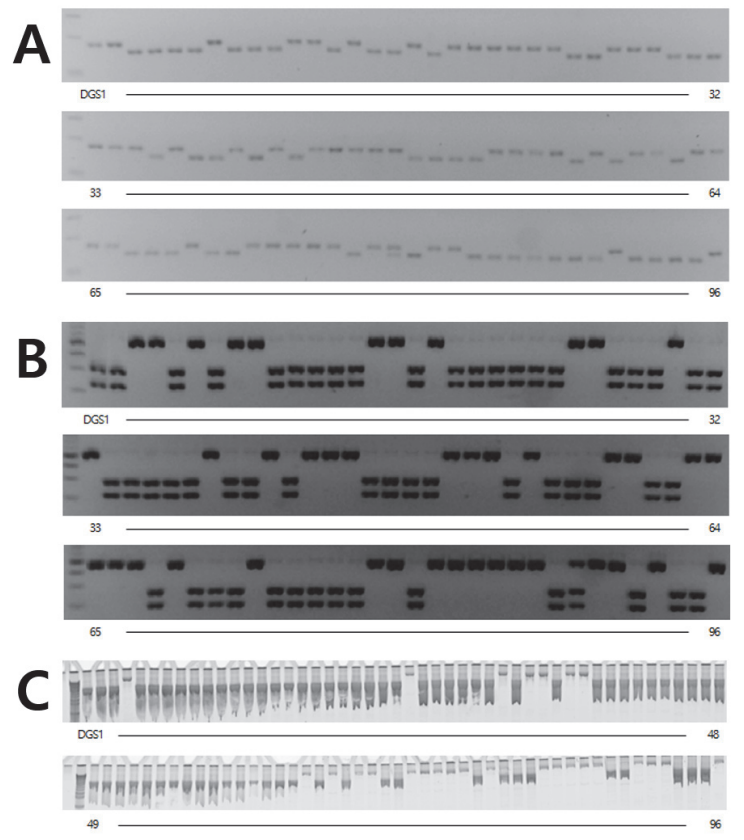

Fig. 5. PCR analysis to confirm the allele types of the breeding materials using gene specific DNA markers. GW2, GS3, and $q S W 5$ were confirmed by PCR products amplified with primer, GW2-Hpa I (cleaved by Hpa I, A), GS3-Pst I (Pst I, B), and N1212del (C). DGS1: Deuraechan, 2: Boramchan, 3: Jizi1560, 4: Jizi1581, 5: Daeripbyeo 1, 6-96: the breeding materials.

Table 10. Number of allele types and frequency of $G W 2, G S 3$, and $q S W 5$ in each group of the breeding materials.

\begin{tabular}{|c|c|c|c|c|c|c|c|c|c|}
\hline \multirow{2}{*}{\multicolumn{2}{|c|}{ Group }} & \multirow[b]{2}{*}{$\mathrm{n}$} & \multicolumn{2}{|c|}{$G W 2$} & \multicolumn{2}{|c|}{ GS3 } & \multicolumn{2}{|c|}{$q S W 5$} & \multirow[b]{2}{*}{ Remark } \\
\hline & & & $g w 2$ & $G W 2$ & $g s 3$ & GS3 & qsw5 & $q S W 5$ & \\
\hline \multirow{5}{*}{ A } & A1 & 6 & 3 & 3 & 6 & 0 & 5 & 1 & Jizi1581 ( $g w 2 g s 3 q S W 5)$ \\
\hline & A2 & 10 & 6 & 4 & 10 & 0 & 1 & 9 & \\
\hline & A3 & 8 & 7 & 1 & 6 & 2 & 8 & 0 & \\
\hline & & 24 & 16 & 8 & 22 & 2 & 14 & 10 & \\
\hline & Total & & $(66.7)^{\mathrm{z}}$ & $(33.3)$ & $(91.7)$ & $(8.3)$ & $(58.3)$ & $(41.7)$ & \\
\hline \multirow{8}{*}{ B } & B1 & 6 & 0 & 6 & 3 & 3 & 6 & 0 & \\
\hline & B2 & 13 & 9 & 4 & 3 & 10 & 11 & 2 & Daeripbyeo 1 (gw2GS3qsw5) \\
\hline & B3 & 7 & 6 & 1 & 2 & 5 & 7 & 0 & \\
\hline & B4 & 4 & 4 & 0 & 1 & 3 & 4 & 0 & \\
\hline & B5 & 4 & 3 & 1 & 3 & 1 & 3 & 1 & \\
\hline & B6 & 4 & 1 & 3 & 3 & 1 & 3 & 1 & \\
\hline & Total & 38 & 23 & 15 & 15 & 23 & 34 & 4 & \\
\hline & & & $(60.5)$ & $(39.5)$ & $(39.5)$ & $(60.5)$ & $(89.5)$ & $(10.5)$ & \\
\hline \multirow{9}{*}{$\mathrm{C}$} & $\mathrm{C} 1$ & 9 & 5 & 4 & 0 & 9 & 8 & 1 & \\
\hline & $\mathrm{C} 2$ & 1 & 0 & 1 & 0 & 1 & 1 & 0 & \\
\hline & $\mathrm{C} 3$ & 5 & 0 & 5 & 0 & 5 & 5 & 0 & Deuraechan (GW2GS3qsw5) \\
\hline & $\mathrm{C} 4$ & 5 & 0 & 5 & 0 & 5 & 4 & 1 & Boramchan (GW2GS3qsw5) \\
\hline & $\mathrm{C} 5$ & 6 & 0 & 6 & 1 & 5 & 1 & 5 & \\
\hline & C6 & 2 & 1 & 1 & 0 & 2 & 1 & 1 & \\
\hline & $\mathrm{C} 7$ & 3 & 0 & 3 & 1 & 2 & 1 & 2 & \\
\hline & Total & 31 & 6 & 25 & 2 & 29 & 21 & 10 & \\
\hline & Total & & $(19.4)$ & $(80.6)$ & (6.5) & $(93.5)$ & $(67.7)$ & $(32.3)$ & \\
\hline \multirow{2}{*}{$\mathrm{D}$} & $D$ & 1 & 1 & 0 & 1 & 0 & 1 & 0 & \\
\hline & $D$ & & $(100)$ & (0) & $(100)$ & (0) & (100) & (0) & Jizil560 (gw2gs3qsw5) \\
\hline \multirow{2}{*}{$\mathrm{E}$} & $\mathrm{F}$ & 2 & 0 & 2 & 2 & 0 & 0 & 2 & DGS79 $83(G W 2 a s 3 a S W 5)$ \\
\hline & $\mathrm{E}$ & & $(0)$ & $(100)$ & $(100)$ & $(0)$ & $(0)$ & $(100)$ & 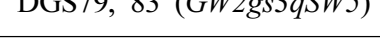 \\
\hline \multirow{2}{*}{\multicolumn{2}{|c|}{ Total }} & 96 & 46 & 50 & 42 & 54 & 70 & 26 & \\
\hline & & & $(47.9)$ & $(52.1)$ & $(43.8)$ & $(56.3)$ & $(72.9)$ & $(27.1)$ & \\
\hline
\end{tabular}

\footnotetext{
${ }^{\mathrm{z}}$ The value in the parenthesis is the frequency of the allele type of $G W 2, G S 3$, and $q S W 5$
} 
(0.290)과 정의 상관을 나타냈고 수장(-0.257)과는 부의 상관을 나타냈다. 간장은 정조수량 $(r=0.209)$ 과 정의 상관을 나타냈고, 수장은 수수 $(r=-0.425)$, 등숙률 $(-0.324)$, 정조수량 $(-0.274)$ 과 부 의 상관을 나타냈다. 수수는 등숙률 $(r=0.462)$, 정조수량 $(0.240)$ 과 정의 상관을 나타냈고 수당립수(-0.451)와는 부의 상관을 나타냈다. 수당립수 $(r=0.507)$ 와 등숙률 $(0.575)$ 은 정조수량과 정 의 상관을 나타냈다.

\section{입형 관련 유전자형 분석}

입형 다양화 육종소재에 대해 입형 관련 주동유전자 $G W 2$, $G S 3, q S W 5$ 의 유전자형을 분석하였다. GW2, GS3, qSW5 각각은 야생형 대립유전자와 기능상실 돌연변이형 대립유전자 두 개의 대립유전자형이 탐지되었다(Fig 5). 우리나라 자포니카 초다수 품종인 드래찬과 보람찬은 $q S W 5$ 이 돌연변이형인 GW2GS3qsw5 유전자형을 나타냈고, 대립형 품종인 대립벼 1 호는 $G W 2$ 와 $q S W 5$ 가 돌연변이형인 $g w 2 G S 3 q s w 5$ 유전자형을 나타냈다. 대립형 유 전자원인 Jizi1581은 $G W 2$ 와 $G S 3$ 가 돌연변이형인 $g w 2 g s 3 q S W 5$ 유전자형을 나타냈고, 입형 크기가 가장 컸던 Jizi1560은 모든 유전자가 돌연변이형인 gw2gs3qsw5 유전자형을 나타냈다. 낟알 의 길이가 길고 너비가 좁아 장폭비가 컸던 그룹 D의 DGS79와 DGS83은 GS3만 돌연변이형인 GW2gs $3 q S W 5$ 유전자형을 나타 냈다. 각 그룹과 소그룹별 입형 관련 유전자의 대립유전자형 빈도는 Table 10 과 같다. 그룹 $\mathrm{A}, \mathrm{B}, \mathrm{C}$ 의 가장 높은 빈도의 유전자형은 각각 $g w 2 g s 3 q S W 5(29.2 \%)$, gw2GS3qsw5(34.2\%), GW2GS3qsw5(48.4\%) 이었다.

\section{유전자가 입형 관련 형질의 표현형 변이에 미치는 영향}

입형 관련 유전자 $G W 2, G S 3, q S W 5$ 가 입형 관련 형질 변이에 미치는 영향에 대해서 분석하였다(Table 11). 세 개 유전자의 단독 작용과 두 개 및 세 개 유전자의 상호작용을 통해서 전체적으 로 설명되는 표현형 변이를 살펴보면 낟알의 길이, 너비, 두께, 장폭비, 천립중의 결정계수가 정조 형질에서 각각 $0.462,0.669$, $0.546,0.654,0.455$ 이고 현미 형질에서 각각 $0.542,0.734$, $0.557,0.755,0.479$ 로 입형 관련 유전자의 작용으로 입형 다양화 육종소재의 입형 관련 형질에 대한 표현형 변이를 정조는 $45 \%$ 이상, 현미는 $54 \%$ 이상을 설명할 수 있었다. 정조 길이에 대해서 는 $G S 3(41.1 \%)$ 와 $G W 2(3.5 \%)$ 가 작용하였고, 현미 길이에 대해 서는 $G S 3(51.3 \%)$ 단독으로 표현형 변이의 $50 \%$ 이상을 설명하 였다. 정조 너비에 대해서는 GW2(34.0\%)와 $q S W 5$ (30.4\%)가 작용하였고 $G S 3$ 와 $q S W 5$ 의 상호작용(1.6\%)이 존재하였으며,
현미 너비에 대해서는 $G W 2(37.2 \%)$ 와 $q S W 5(32.7 \%)$ 가 표현형 변이의 $70 \%$ 가량을 설명하였고 $G S 3$ 와 $S W 5$ 의 상호작용 $(2.6 \%)$ 이 존재하였다. 낟알의 두께에 대해서는 $G W 2(27.6,26.8 \%$; 정조 및 현미)와 $q S W 5(25.1,26.5 \%)$ 가 비슷한 수준으로 표현형 변이 에 영향을 미쳤다. 낟알의 장폭비에 대해서는 $G S 3(26.6,38.3 \%$; 정조 및 현미), $q S W 5(19.1,20.4 \%), G W 2(15.6,13.1 \%)$ 순으로 표현형 변이에 영향을 미쳤으며, $G W 2$ 와 $G S 3$ 의 상호작용(2.2, $1.4 \%)$ 이 존재하였다. 낟알의 천립중은 $G W 2(20.2,18.2 \%$; 정조 및 현미), $G S 3(12.6,17.4 \%), q S W 5(11.7,9.9 \%)$ 순으로 표현형 변이에 영향을 미쳤다. 입형 관련 유전자의 대립유전자형에 따른 입형 관련 형질 값을 비교 분석하였다(Table 12). 세 개의 유전자 모두 기능상실 돌연변이형 대립유전자인 $g w 2, g s 3, q s w 5$ 가 야생 형 대립유전자 $G W 2, G S 3, q S W 5$ 에 비해 낟알의 크기가 증가하는 방향으로 작용하였다. $g w 2$ 는 $G W 2$ 에 비해 정조의 길이, 너비, 두께, 천립중 및 현미의 너비, 두께, 천립중이 증가하였으며, 정조와 현미의 장폭비는 감소하였다. $g s 3$ 는 $G S 3$ 와 낟알의 너비 와 두께는 차이가 없었으나 gs3가 $G S 3$ 에 비해 낟알 길이가 길어져 장폭비가 커지고 천립중이 증가하였다. $q s w 5$ 와 $q S W 5$ 는 낟알의 길이에는 차이가 없으나 $q s w 5$ 가 $q S W 5$ 에 비해 너비와 두께가 커지고 천립중이 증가하였으며 장폭비는 감소하였다. 입형 다양 화 육종소재는 세 개의 유전자로 작성 가능한 모든 대립유전자 조합인 8개의 유전자형이 탐지되었다. 유전자형별 형질 값을 비교해 보면 낟알의 길이는 $G S 3$ 의 대립유전자형에 의해 차이가 구분되었는데 $g s 3$ 대립유전자를 가지고 있는 유전자형이 GS3 대립유전자를 가지고 있는 유전자형에 비해 낟알의 길이가 길었 다(Fig. 6). 너비와 두께는 $G W 2$ 와 $q S W 5$ 의 대립유전자 조합에 의해 형질 값의 차이가 구분되었는데 $g w 2 q s w 5$ 가 형질 값이 가장 크고 $g w 2 q S W 5$ 와 $G W 2 q s w 5$ 가 통계적으로 같은 그룹으로 분류되 었으며 $G W 2 q S W 5$ 가 값이 가장 작았다. 장폭비와 천립중은 $G W 2$, $G S 3, q S W 5$ 세 개의 유전자 모두가 관여하여 작성된 대립유전자 조합의 유전자형에 의해 형질 값이 구분되었다. 장폭비는 $G W 2$ 와 $q S W 5$ 가 야생형 대립유전자이면서 $G S 3$ 만 기능상실 돌연변이형 대립유전자인 GW2gs $3 q S W 5$ 유전자형이 장원형에 속하는 현미 장폭비 2.56으로 가장 큰 장폭비를 보였으며 $g w 2 g s 3 q S W 5$ (현미 장폭비 2.18), GW2gs3qsw5(2.15), GW2GS3qSW5(2.05)이 중원 형에 속하면서 중간 값을 나타냈고 $g w 2 g s 3 q s w 5(1.92)$, gw2GS3qSW5(1.81), GW2GS3qsw5(1.74), gw2GS3qsw5(1.67) 이 단원형에 속하면서 값이 작았다. 천립중은 세 개의 유전자가 모두 기능상실 돌연변이형 대립유전자인 gw2gs $3 q s w 5$ 유전자형 이 가장 무거운 값(44.4, $36.6 \mathrm{~g}$; 정조 및 현미)을 나타냈으며 

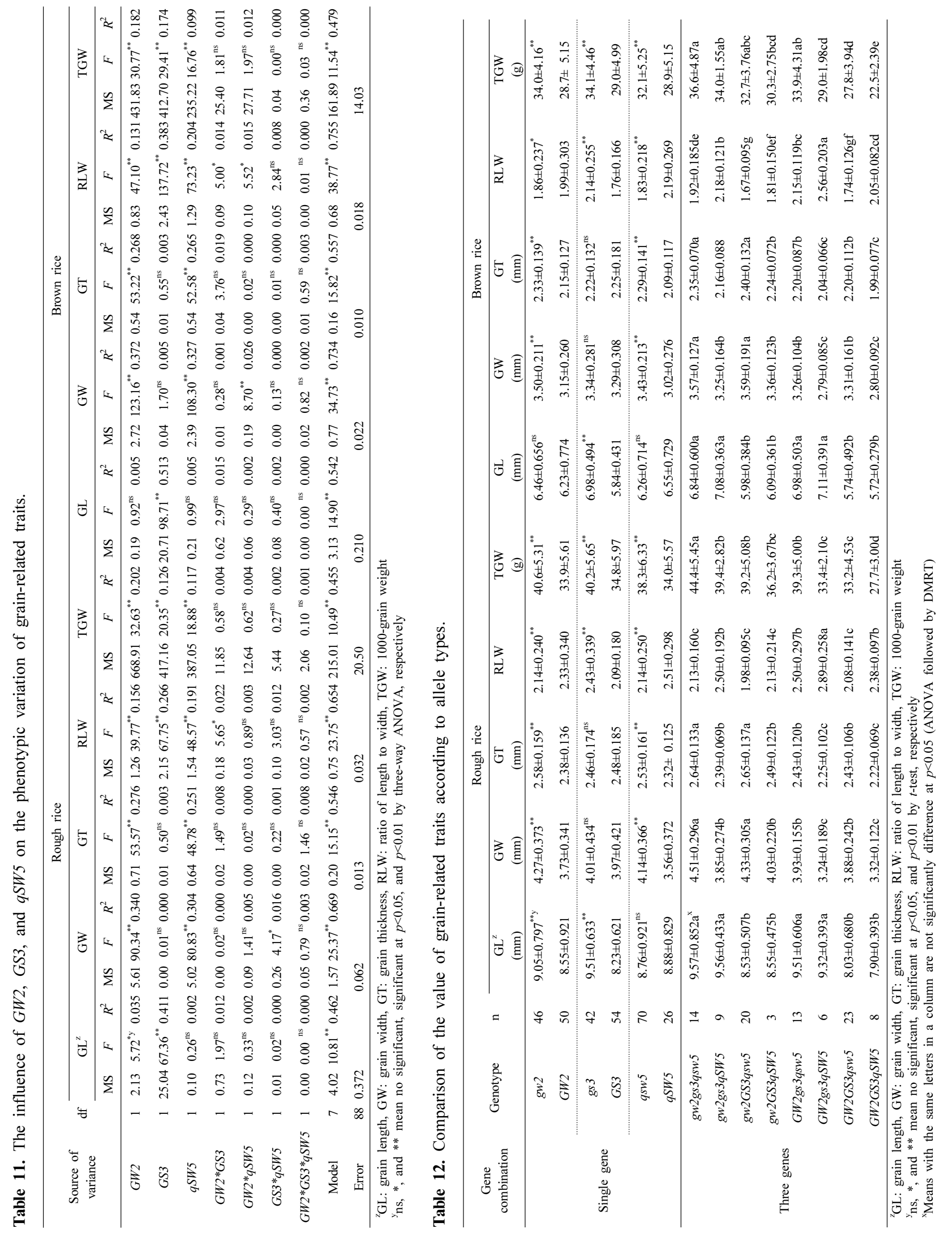

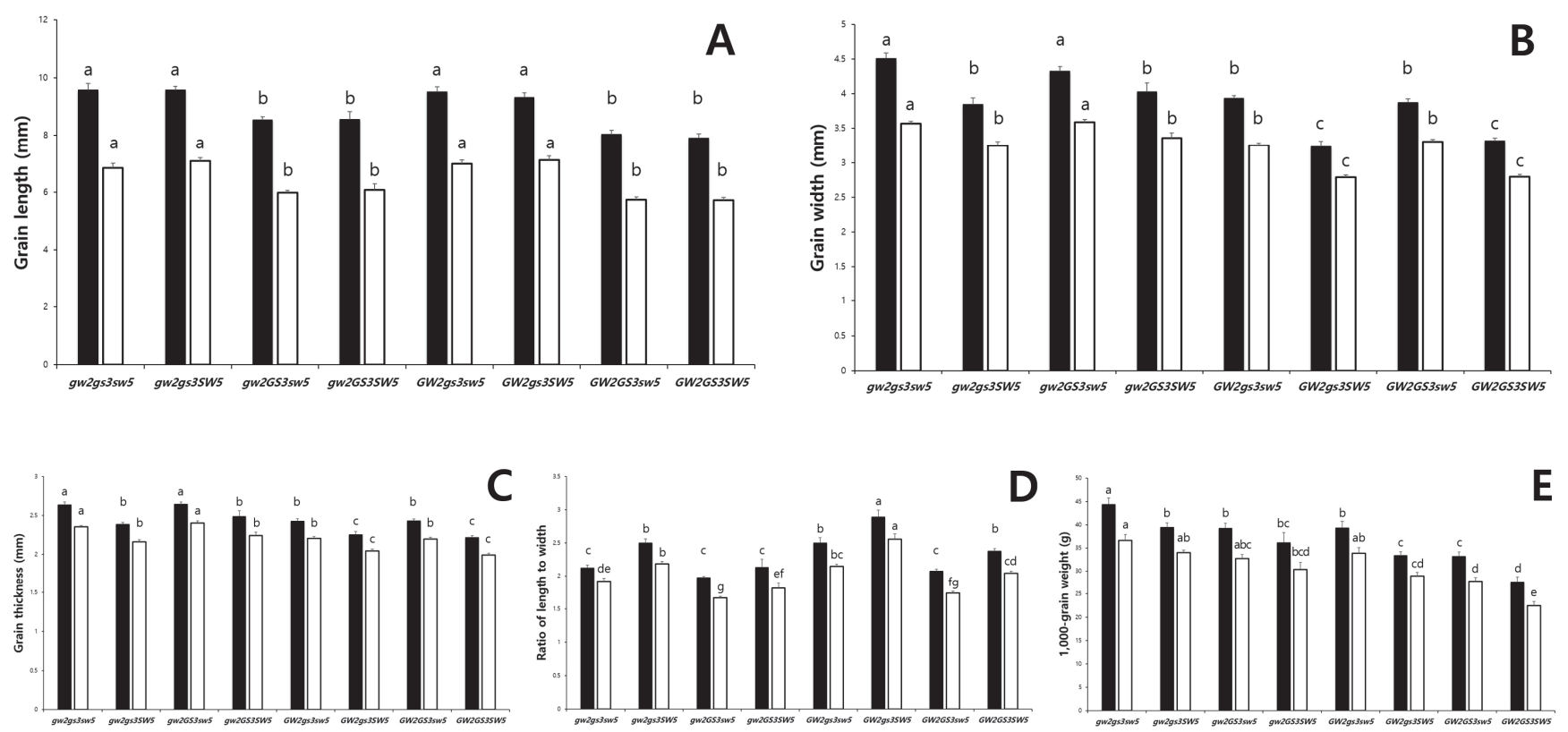

Fig. 6. Comparison of the genetic effects of $G W 2, G S 3$, and $q S W 5$ on grain length (A), grain width (B), grain thickness (C), ratio of length to width (D), and 1,000-grain weight (E). Gene symbols of small and capital letters indicate homozygote alleles with loss-of-function mutant type and function wild type of $G W 2, G S 3$, and $q S W 5$, respectively. Solid bar and open bar indicate rough rice and brown rice, respectively. Comparison was carried out in each rough and brown rice by Duncan's multiple range test. Different letters over the bars indicate significant differences at $p<0.05$.

그 다음으로 $g w 2 g s 3 q S W 5(39.4,34.0 \mathrm{~g}), G W 2 g s 3 q s w 5(39.3,33.9$

$\mathrm{g}), g w 2 G S 3 q s w 5(39.2,32.7 \mathrm{~g})$ 가 비슷한 수준으로 무거웠다. 세 개의 유전자 중 하나만 야생형 대립유전자인 $g w 2 G S 3 q S W 5(36.2,30.3$ $\mathrm{g}$; 정조 및 현미), GW2gs3qSW5(33.4, $29.0 \mathrm{~g})$, GW2GS3qsw5(33.2, $27.8 \mathrm{~g})$ 유전자형 중에서는 $g w 2$ 형이 $g s 3$ 와 $s w 5$ 에 비해 무거운 천립중 을 나타냈다. 모든 유전자가 야생형 대립유전자를 가지고 있는 $G W 2 G S 3 q S W 5(27.7,22.5 \mathrm{~g})$ 유전자형의 천립중이 가장 가벼웠다.

\section{유전자가 수량 관련 형질의 표현형 변이에 미치는 영향}

입형 관련 유전자 $G W 2, G S 3, q S W 5$ 가 수량 관련 형질 변이에 미치는 영향에 대해서 분석하였다(Table 13). 출수기와 간장은 유전자의 작용에 의해 전체적으로 설명되는 표현형 변이가 통계 적으로 유의하지 않았고 수장, 수수, 수당립수, 등숙률, 정조수량 은 통계적으로 유의한 수준에서 결정계수가 $0.265,0.323,0.204$, $0.392,0.222$ 로 형질 변이의 $20 \%$ 이상을 설명할 수 있었다. 수장에 대해서는 $G S 3(16.3 \%)$ 가 표현형 변이에 작용하였고 $G S 3$ 와 $q S W 5$ 의 상호작용 $(6.3 \%)$ 이 존재하였다. 수수는 $G W 2(25.1 \%)$ 와 $q S W 5(3.9 \%)$ 가 작용하였고, 수당립수는 $q S W 5(12.8 \%)$ 가 작 용하였으며 $G S 3$ 와 $q S W 5$ 의 상호작용(3.7\%)이 존재하였다. 등숙
률은 $G S 3(17.4 \%), G W 2(16.1 \%), q S W 5(3.4 \%)$ 순으로 표현형 변이에 영향을 미쳤으며, 정조수량에 대해서는 $G S 3(9.9 \%)$ 와 $q S W 5(6.3 \%)$ 가 작용하였다. 입형 관련 유전자의 대립유전자형 에 따른 수량 관련 형질 값을 비교 분석하였다(Table 14). 기능상 실 돌연변이형 대립유전자인 $g w 2$ 를 보유하고 있는 자원은 야생 형 대립유전자 $G W 2$ 를 가지고 있는 자원에 비해 수수가 적었고 등숙률과 정조수량이 낮았다. $g s 3$ 를 보유하고 있는 자원은 GS3 를 가지고 있는 자원에 비해 출수가 빠르며 수장이 길고 등숙률과 정조수량은 낮았다. $q s w 5$ 를 보유하고 있는 자원은 $q S W 5$ 를 가지 고 있는 자원에 비해 수수가 많았고 수당립수는 적었다. 유전자형 별 형질 값을 살펴보면 모든 유전자가 기능상실 돌연변이형 대립유전자인 $g w 2 g s 3 q s w 5$ 유전자형이 다른 유전자형에 비해 수수가 적고 등숙률이 낮으며 수당립수와 정조수량이 가장 적은 반면, 모든 유전자가 야생형 대립유전자인 GW2GS3qSW5 유전 자형은 수수와 수당립수가 많은 편이었으며 등숙률이 가장 높았 고 정조 수량도 두 번째로 많았다. 유전자형 중에 $G W 2$ 와 GS3의 대립유전자형이 같을 경우 $q S W 5$ 를 보유한 자원이 $q s w 5$ 를 보유 한 자원에 비해 통계적으로 수당립수가 많고 등숙률이 높았으며 정조수량이 많았다. 

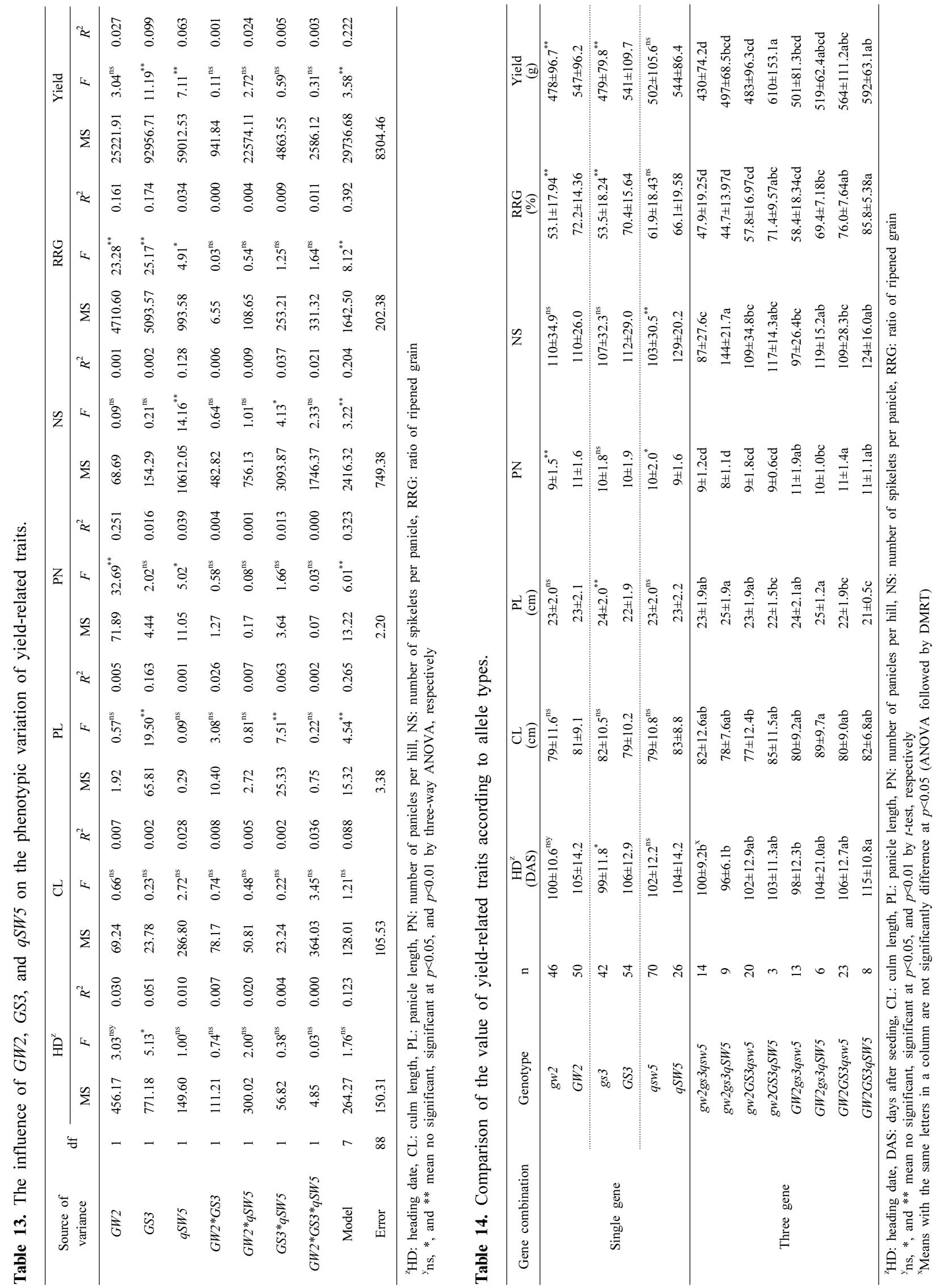


\section{고 찰}

\section{입형 다양화 육종소재의 입형 관련 형질 다양성}

우리나라 자포니카 벼의 협소한 입형 특성을 다양화하기 위해 서 자포니카 대립형 유전자원을 교배모본으로 활용하여 입형이 다양화된 육종소재를 개발하였다. 입형 다양화 육종소재는 우리 나라 육성 품종들에 비해 다양한 입형 특성을 나타냈다. 입형을 구분하는 국제적인 기준은 정해져 있지 않고 각기 다른 기준을 사용하고 있다. 국제미작연구소에서는 현미 길이를 기준으로 $7.5 \mathrm{~mm}$ 이상 초장립종(extra long), 6.6-7.0 mm는 장립종(long) 5.5-6.5 mm는 중립종(medium), $5.5 \mathrm{~mm}$ 미만은 단립종(short) 으로 구분하며, 현미 장폭비를 기준으로 3.0 이상을 세장형 (slender), 2.1-3.0을 중원형(medium), 1.1-2.0을 단원형(blod), 1.1 이하를 원형(round)으로 구분한다(SES 2014). FAO에서는 장폭비, 낟알 길이, 장폭비와 낟알 길이 동시 고려 등 세 가지 유형으로 장립종(long grain), 중립종(medium grain), 단립종 (short grain)을 분류한다. 장폭비를 기준으로 장립종은 3.1(현미 기준)과 3.0(백미) 이상, 중립종은 2.1-3.0(현미)와 2.0-2.9(백 미), 단립종은 2.0 (현미)과 1.9 (백미) 이하로 구분하고, 낟알 길이 를 기준으로 $6.6 \mathrm{~mm}$ 이상은 장립종, $6.2-6.6 \mathrm{~mm}$ 은 중립종, $6.2 \mathrm{~mm}$ 이하는 단립종으로 구분하다. 장폭비와 낟알 길이를 동시에 고려해서는 낟알 길이 $6.0 \mathrm{~mm}$ 이상이고 장폭비 2.0-3.0 이거나 3.0 이상을 장립종, 낟알 길이 5.2-6.0 mm이고 장폭비 3.0 이하는 중립종, 낟알 길이 $5.2 \mathrm{~mm}$ 이하이거나 장폭비 2 이하는 단립종으로 구분한다(CODEX STAN 198-1995). 우리 나라는 현미 길이를 기준으로 $5.00 \mathrm{~mm}$ 이하는 단립종(S; short), 5.01-5.55 mm는 중단립종(MS; medium-short), 5.51-6.00 mm 는 중립종(M; medium), 6.01-7.00 mm 이상 장립종(L; long), $7.01 \mathrm{~mm}$ 이상 초장립종 (EL; extra long)으로 구분(RDA 2012) 하며, UPOV 기준을 따라 현미의 형태를 장폭비 1.5 이하를 원형 (round), 1.50-1.99를 단원형(semi-round), 2.00-2.49를 중원형 (half spindle-shaped), 2.50-2.99를 장원형(spindle-shaped), 3.00 이상을 세장형(long spindle-shaped)으로 구분한다(KSVS 2005). 개발된 입형 다양화 육종소재는 현미 길이 5.09-7.69 mm 로 단립종, 중립종, 장립종, 초장립종 모두를 포함하고 있었으며, 현미 장폭비 1.53-2.83으로 단원형, 중원형, 장원형의 입형 특성 을 나타냈다(Table 7). 이에 반해 우리나라 자포니카 품종의 대부분은 단립종에 단원형의 입형 특성을 나타냈고, 통일형 품종 은 중립종에 중원형 입형 특성을 나타냈다. 32 개 통일형 품종 중 장원형에 속하는 품종은 안다, 삼성 2품종 뿐이었고 남천,
아름, 목양 3품종은 단원형에 속하는 등 인디카자포니카 생태형 인 통일형 품종도 입형이 길지 않고 둥근 형태를 나타낸 것은 단원형을 선호하는 시장 요구가 육종과정 중에 반영되어 선발압 으로 작용한 결과로 생각된다. 입형 다양화 육종소재 중 그룹 E에 속하는 DGS79와 DGS83은 현미 길이 $7.52 \mathrm{~mm}$ 로 초장립종 이며 너비 $2.71,2.66 \mathrm{~mm}$ 로 장폭비 $2.78,2.83$ 의 장원형에 속하 는 등 기존 육성 품종과 개발된 육종소재와 비교해 볼 때 특이한 입형 특성을 나타냈다.

\section{입형 및 수량 관련 형질들간의 관련성}

낟알의 크기는 낟알의 길이, 너비, 두께 등에 의해 결정되며 주당수수, 수당립수와 함께 $\operatorname{sink}$ 를 결정짓는 요인이다. 입형 다양화 육종소재의 낟알 길이, 너비, 두께는 주당수수, 수당립수 와 대부분 부의 상관관계를 나타내(Table 9) 낟알의 크기 증가가 실질적인 sink의 증가로 이어지지 않을 수 있으며, 등숙률과의 부의 상관 관계는 source에 부정적으로 작용할 수 있음을 알려준 다. 벼 수량성은 여러 형질이 관여하는 양적 형질로서 식물체의 광합성에 의해 동화산물이 생성되고 전류되는데 관여하는 능력 인 source와 종실에 축적될 수 있는 잠재력인 sink에 의해 결정되 며 sink가 작으면 높은 수량을 기대하기 어렵고 sink가 크다 해도 source가 이를 뒷받침해주지 못하면 수량성은 향상되지 않아 sink와 source의 크기와 균형이 중요하다 하였다(Hirota et al. 1990, Li et al. 1998, Park et al. 2015). 낟알의 크기를 증가시켜 수량성을 향상하고자 할 경우 수당립수와 수수의 감소 를 줄여 sink를 확대하고 등숙률 감소를 극복하기 위한 source 능력을 향상시키는 것이 중요할 것으로 생각한다. 입형 다양화 육종소재의 장폭비는 낟알의 길이와 정의 상관을 나타내고 너비 와 두께와는 부의 상관관계를 나타내나 sink와 관련된 천립중 및 수당립수와는 통계적으로 유의한 관련성이 없으며 source 능력과 관련된 등숙률과 최종적인 수량에도 관련이 없어 장폭비 의 변화는 수량성에 부정적인 영향을 미치지 않을 것으로 판단되 었다. 벼 소수의 등숙은 낟알의 길이 방향으로 먼저 채워지고 그 다음 너비와 두께로 채워지기 때문에 수량성 확보측면에서는 장립형이 적합하다 하였고(Lee et al. 2003), 300여개 유전자원 에 대한 심복백과 같은 분상질립을 조사한 결과 분상질립은 낟알의 너비와는 정의 상관 $(r=0.55)$ 을 나타낸 반면 길이 $(-0.17)$ 와 장폭비(-0.44)와는 부의 상관을 나타낸다 하여 외관품위 측면 에서 장폭비가 큰 입형이 적합하다 하였다(Koutroubas et al. 2004). 기후변화로 인한 기온 상승은 전세계적으로 벼의 수량과 품질에 악영향을 미치고 있고(Krishnan et al. 2011), 우리나라 

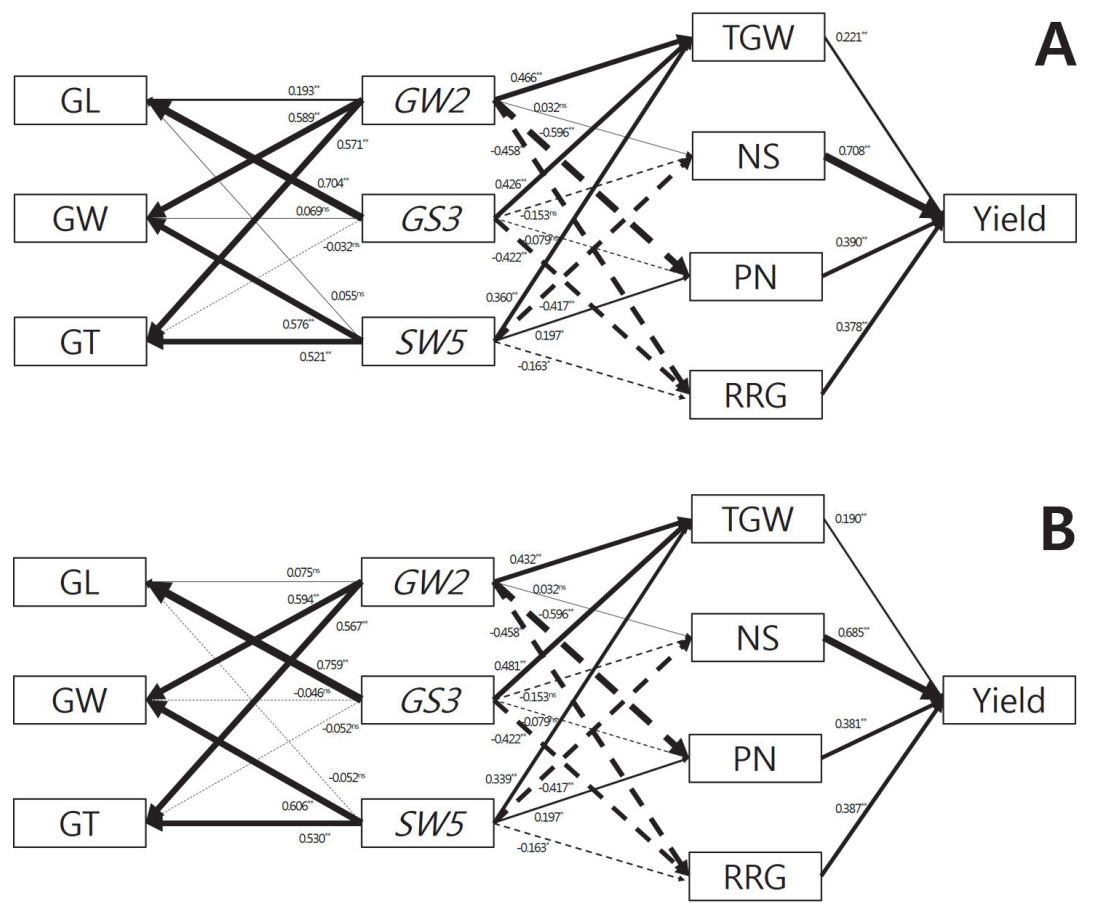

Fig. 7. Path analysis diagram for the influence of loss-of-function allele types of grain size-related genes $G W 2$, GS3, and $q S W 5$ on the grain and yield-related traits of rough (A) and brown rice (B). GL, GW, GT, TGW, NS, PN, and RRG mean grain length, grain width, grain thickness, 1,000-grains weight, number of spikelets per panicle, number of panicles per hill, and ratio of ripened grain, respectively. Continuous and dotted arrows indicate positive and negative effects, respectively. The arrow line thickness means proportion of the effect. ns, *, and ** indicate no significant, significant at 5 and $1 \%$ probability level, respectively.

역시 기후변화에 따른 문제가 발생(Lee et al. 2012)하고 있어 이를 극복하기 위한 방안이 필요한 실정이다. 장폭비의 변경은 수량을 감소시키지 않으면서 외관품위도 향상시킬 수 있는 가능 성이 있기 때문에 기존 우리나라 재배 품종의 획일화된 단원형 입형에서 탈피하여 중원형, 장원형 및 세장형으로 입형을 다양하 게 변경하기 위한 육종적 노력이 필요하다고 생각한다.

\section{유전자형이 입형 및 수량 관련 형질에 미치는 영향}

입형 관련 주동 유전자 $G W 2, G S 3, q S W 5$ 가 입형 다양화 육종 소재의 입형 및 수량 관련 형질 각각에 미치는 영향에 대해 분석하였다. 세 개 유전자 모두 기존의 연구결과에서 밝혀졌던 야생형 및 기능상실 돌연변이형 대립유전자 2개의 대립유전자로 구분되었고(Fig. 5), 기능상실 돌연변이형 대립유전자 모두 낟알 의 크기가 커지는 방향으로 작용하였다. 기능상실 돌연변이형 대립유전자들이 입형 관련 형질인 낟알 길이, 너비, 두께와 sink 관련 형질인 천립중, 수당립수, 수수와 source 관련 형질인 등숙 률에 대한 기여도를 분석하였다(Fig. 7). 낟알 길이에 대해서는 gs 3 가 표준화 회귀계수 0.704(정조)와 0.759(현미)로 길이를 증가시키는 방향으로 큰 기여도를 나타냈다. $g w 2$ 는 정조 길이에 대해서는 일부 기여하였으나 현미에서는 통계적으로 유의하지 않았는데, 이는 정조 길이가 늘어나 커진 sink 를 등숙 과정에서 채워주지 못하기 때문에 $g w 2$ 가 정조와 현미 길이에 기여하는 바가 다른 것으로 생각된다. $q s w 5$ 는 정조와 현미 길이에 관여하 지 않는 것으로 나타냈다. 낟알 너비와 두께에 대해서는 $g_{s} 3$ 는 관여하지 않고 $g w 2$ 와 $q s w 5$ 가 기여하는 것으로 나타났다. 낟알 두께에 대해서는 정조와 현미 모두에서 $g w 2$ 가 $q s w 5$ 에 비해 기여도가 다소 높았다. 너비에 대해서 정조에서는 $g w 2$ 가 기여도 가 높은 반면 현미에서는 $q s w 5$ 가 높았는데 이는 $g w 2$ 가 $q s w 5$ 에 비해 등숙 전 소수의 너비 증가에 더 크게 작용한데 반해, 등숙률 에서는 $g w 2$ (표준화 회귀계수 -0.458)가 $q s w 5(-0.163$ )에 비해 감소하는 방향으로 기여도가 큰 것을 볼 때 등숙 과정에서 $g w 2$ 가 $q s w 5$ 에 비해 커진 $\operatorname{sink}$ 를 채워주는 능력이 부족하여 일어난 것으로 생각되었다. 천립중의 경우 정조에서는 $g w 2, g s 3, q s w 5$ 순 으로 증가하는 방향으로 기여도가 컸으나 현미에서는 $g s 3, g w 2$, 
$q s w 5$ 순으로 변경되어 이 또한 $g w 2$ 가 커진 $\operatorname{sink}$ 를 채워주는 능력이 부족한 것에 기인한 것으로 생각되었다. 수당립수에 대해 서는 $g w 2$ 와 $g s 3$ 는 유의한 기여도가 없었으나 $q s w 5$ 는 수당립수 가 줄어드는 방향으로 영향을 미쳤고, 수수에 대해서는 $g s 3$ 는 영향이 없었으나 $q s w 5$ 는 증가하는 방향으로 다소 기여하였으며 $g w 2$ 는 감소하는 방향으로 크게 작용하였다. 등숙률에 대해서는 낟알 크기가 증가하는 기능상실 돌연변이형 대립유전자 모두 감소하는 쪽으로 기여하였으며 $g w 2, g s 3, q s w 5$ 순으로 그 기여도 가 컸다. 정조 수량에 대해서는 수당립수, 수수, 등숙률, 천립중 순으로 기여도가 커 낟알크기가 수량에 미치는 영향은 다른 수량 관련 형질에 비해 적었다. 세 개의 유전자의 대립유전자형 조합에 따른 형질 값을 보면 모든 유전자가 기능상실 돌연변이형 인 $g w 2 g s 3 q s w 5$ 유전자형이 낟알 크기가 가장 크고 무거웠다. 이 조합은 낟알의 길이와 너비가 함께 증가하여 평균 현미 장폭비 1.92 의 단원형이었고 낟알의 크기가 가장 큰 교배모본 Jizi1560 이 여기에 속하였다. 기존의 연구결과에서 Jizi1560은 $G W 2$ 와 $q S W 5$ (Ying et al. 2012), GL3.1(Qi et al. 2012)의 기능상실 돌연변이형 대립유전자를 가지고 있다고 하였으며, 본 연구결과 에서도 $g w 2$ 와 $q s w 5$ 를 가지고 있었고 $g l 3.1$ 에 대한 분석을 수행하 지 않아 확인을 못하였으나 같은 3 번 염색체에 연관되어 있는 길이 관련 주동 유전자 gs3가 탐지되어 큰 입형 특성을 나타냈다. 또다른 대립 유전자 Jizi1581이 속한 $g w 2 g s 3 q S W 5$ 유전자형 조합은 평균 현미 장폭비 2.18의 중원형에 속하였다. 우리나라 육성 품종 중 천립중이 가장 무거운 대립벼 1 호는 $g w 2 G S 3 q s w 5$ 유전자형을 가지고 있었는데 이 조합은 평균 현미 장폭비 1.67 로 장폭비가 가장 작은 단원형에 속하였다. 교배모본인 드래찬과 보람찬 모두 $q S W 5$ 만 기능상실 돌연변이형 대립유전자를 가지고 있는 GW2GS3qsw5 유전자형에 속하였는데 이 조합은 평균 현미 장폭비 1.74로 단원형에 속하였다. GW2GS3qsw5 유전자형은 입형과 크기가 우리나라 자포니카 품종들과 비슷하며 일부 육성 품종에 대한 분자표지 검정결과(data not shown)를 고려할 때 우리나라 자포니카 밥쌀용 품종들은 대부분 GW2GS3qsw5 유전 자형을 가지고 있을 것으로 판단되며 향후 이에 대한 정확한 분석이 필요할 것으로 생각한다. 모든 유전자가 야생형 대립유전 자인 GW2GS3qSW5 유전자형은 천립중이 가장 작고 낟알의 길이는 GW2GS3qsw5와 비슷하나 너비가 좁아 평균 현미 장폭비 2.05 의 중원형에 속하였다. GW2GS3qSW5 유전자형은 GW2GS3qsw5에 비해 수당립수가 많고 등숙률이 높아 정조 수량 도 많았는데 이는 $q S W 5$ 의 작용에 의한 것으로 생각된다. GS3만 기능상실 돌연변이형인 GW2gs $3 q S W 5$ 유전자형은 특이한 입형
특성을 나타낸 DGS79와 DGS83이 속한 조합으로 낟알의 길이 가 길고 너비가 좁아 평균 현미 장폭비 2.56 의 장원형 특성을 나타냈다.

\section{입형 다양화 육종소재의 적용}

입형 특성은 수량과 품질에 중요한 역할을 한다. 우리나라 자포니카 벼는 협소한 입형 특성을 가지고 있다. 자포니카 벼의 정체되어 있는 수량성 장벽과 기후변화에 따른 품질저하 극복을 위한 기반연구와 더불어 새로운 품질에 대한 소비자의 요구 충족과 쌀 산업 발전을 위한 사회적 변화를 견인하기 위해서는 우리나라 자포니카 벼 품종의 입형 특성을 다양화해야 한다. 입형 다양화를 위한 효율적인 육종사업을 수행하기 위해서는 다양한 입형 특성을 가지고 있으면서 육성과정 중에 열악형질이 수반되지 않는 교배모본이 필요하다. 이를 위해 자포니카 벼의 밥맛 및 이화학적 특성을 유지하면서 교잡시 불친화성이 없도록 자포니카형이면서 대립형 입형 특성을 가지고 있는 유전자원 Jizi1560과 Jizi1581을 탐색하여 입형 다양화를 위한 수여친으 로 활용하였다. 입형 및 농업형질 특성을 통해 선발된 입형 다양 화 육종소재는 다양한 입형 특성을 갖추고 있는 자포니카형 자원으로 육종사업에 바로 적용이 가능하며 자원의 보존과 활용 을 위해 농업유전자원센터에 기탁되었다. 단원형 입형을 선호하 는 우리나라 소비자와 시장성을 고려하면 국내 소비 밥쌀용 쌀에 있어서 세장형과 같은 급격한 입형의 변경은 어려울 것으로 생각되나, 낟알의 길이는 비슷한 수준에서 너비를 줄여 중원형 입형으로의 변경은 가능할 것으로 생각한다. 입형 관련 유전자 조합 중 중원형 입형 특성을 나타내는 GW2GS3qSW5 유전자형 의 경우 입형의 변경과 더불어 등숙률과 수량성이 향상되는 것으로 나타나 활용할 가치가 있다고 판단되었고, 이를 국내 소비 밥쌀용 벼 품종의 새로운 목표 유전자 조합으로 선정하여 육종사업에 적용하고 있다. 이를 위해 GW2GS3qSW5를 가지고 있는 중원형 DGS77 계통은 ‘전주598호'로 명명되어 직접적으 로 농업형질 특성에 대한 검토가 이루어졌고, 이를 교배모본으로 활용하여 중원형 우량 계통 개발을 위한 육종사업이 수행되고 있다. 최근의 쌀 소비 감소는 벼 육종사업에서 밥쌀용 이외의 용도를 가진 벼 품종 개발을 촉구하고 있다. 이러한 발로에서 쌀가루용 벼 품종이 개발되고 있다. 건식 제분에 적합한 분질 배유형 유전자 flo7(t)(Mo et al. 2013)를 가지고 있는 '수원542 호를 개발하고 이를 이용한 후대 계통이 육성되고 있으며, '설갱 벼'의 연질 관련 형질특성(Kwak et al. 2017)을 이용하여 쌀가루 전용 품종을 개발하고 있다. 특히 대립벼 1 호와 설갱벼를 이용하 
여 개발된 대립연질미 '한가루'는 기존의 연질미 특성에 부가적 으로 대립벼1호의 $g w 2$ 를 도입(Shim et al. 2016)하여 낟알 크기 를 증가시킴으로써 일반적으로 낟알 크기 증가 시 잘 분쇄되고 등숙이 저하(Kato 1986)되는 반대 효과를 이용하여 제분효율을 증가시키고자 개발되었다. 이러한 관점에서 분질 관련 유전자 $f l o 7$ 에 부가적으로 $g w 2, g s 3, q s w 5$ 를 집적하여 낟알 크기를 확대 함으로써 제분효율을 증진시키고자 하는 육종사업이 수행되고 있다. 현재 우리나라에서 생산하는 수출용 쌀은 국내 소비 밥쌀용 쌀과 같은 자포니카 단립종 단원형 쌀이다. 국내 생산 쌀의 국외 수출은 지속적인 쌀 소비 감소에 따른 쌀 가격 하락을 보완해 줄 수 있는 방안으로 2007년 처음으로 18 개국에 566톤을 시작으 로 2009년에는 37개국에 4,495톤까지 수출량이 늘었지만 그 후 정체상태에 있는 실정이다(Ko et al. 2017). 2016년 중국과의 쌀 수출 협상이 타결됨에 따라 중국으로의 쌀 수출 길이 열렸다. 중국 내에서 자포니카 벼 재배면적과 생산량은 지속적으로 증가 (Hansen et al. 2002)하고 있으며 특히 흑룡강성 우창지역에서 생산되는 쌀은 고급 쌀로 인식되며 고가로 팔리고 있다. 우리나라 수출쌀과 중국 흑룡강성의 최고급 쌀인 우창쌀, 일본과 대만산 수출쌀에 대한 품질을 비교 분석한 결과 우리나라, 일본, 대만산 수출쌀은 단립종 길이에 단원형 입형을 나타낸 반면 우창쌀은 중립종 길이에 장폭비 2.51의 장원형 입형을 나타냈다(Ko et al. 2017). 중국 내 최고급쌀로 인정받고 있는 자포니카 쌀인 우창쌀의 입형이 우리나라 품종과 다르다는 것은 기존의 단립종 의 단원형 입형 특성에서 탈피하여 중립종 및 장립종의 장원형 입형 특성을 가진 쌀도 대중국 수출용 쌀로 그 경쟁 가능성이 있음을 시사해준다. 또한 많은 국가에서 낟알이 길이가 길고 너비가 얇은 쌀은 선호하는 경향(Calingacion et al. 2014)은 자포니카 장원형 쌀의 수출 다변화에 유리한 점으로 작용할 수 있을 것이다. 육안으로도 구분이 용이한 장원형 쌀을 수출 전용으로 활용할 경우 아직까지 장원형 쌀에 대한 선호가 낮은 국내에서 수출을 목적으로 생산된 쌀이 수출 여건 변화에 의해 국내 소비 밥쌀용으로 흡수되는 것을 방지할 수 있어 쌀 가격 하락에 영향을 미치지 못할 것이며 이는 수출용 쌀 생산단지의 수출 의욕 고취에 기여할 것으로 생각한다. GS3만 기능상실 돌연변이형인 GW2gs $3 w q S W 5$ 유전자형은 장립종이면서 장원형 입형 특성을 나타내 이러한 목적을 달성할 수 있는 목표 조합으로 판단되었고 이를 육종사업에 반영하였다. GW2gs $3 q S W 5$ 유전자 형을 가지고 있으면서 낟알이 가장 길고 장폭비가 가장 커서 다른 자원과 구별되었던 DGS79와 DGS83이 교배모본으로 활 용되었고 이들이 가지고 있는 늦은 출수기, 긴 까락, 쳐진 지엽
등 열악형질을 제거하는 육종사업이 수행되어 장립종에 장원형 인 다수성 계통이 육성되었고 생산력검정시험에 공시 중에 있다. 또한 수출 경쟁력 강화를 위해 개발된 장원형 우량계통의 수량성 증진과 품질 향상, 내병성 강화를 위한 육종사업 또한 수행되고 있다.

\section{적 요}

벼 낟알의 크기와 형태는 수량과 품질에 중요한 역할을 한다. 대부분의 우리나라 자포니카 벼 품종은 중소립 단립종에 단원 형 입형 특성을 나타낸다. 이러한 협소한 입형 특성을 다양화하 고자 ‘입형 다양화 육종소재’를 개발하였고 이들의 형질 특성 분석과 입형 관련 유전자와의 관련성을 구명하였다. 자포니카 대립형 유전자원 'Jizi1560', 'Jizi1581'과 우리나라 자포니카 초다수성 품종 '드래찬', '보람찬’을 교배한 4조합의 $\mathrm{F}_{1}$ 식물체 를 이용하여 약배양을 수행하였고 농업형질이 양호한 290 개 약배양 계통을 선발하였다. 포장조사를 통해 입형 특성이 다양화 된 91개 계통을 선발하여 입형 다양화 육종소재라 명명하고 입형 및 수량 관련 형질 특성을 분석하였다. 개발된 입형 다양화 육종소재는 기존의 우리나라 육성 벼 품종에 비해 다양한 입형 특성을 나타냈다. 입형 관련 주동 유전자 $G W 2, G S 3, q S W 5$ 에 대한 유전자형 분석을 통하여 유전자와 입형 및 수량 관련 형질들과의 관련성을 분석하였다. 세 개의 유전자 모두 기능상 실 돌연변이형 대립유전자가 낟알의 크기를 증가시키는 방향으 로 작용하였다. 낟알 길이에 대해서는 $g s 3$, 낟알 너비와 두께에는 $g w 2$ 와 $q s w 5$ 가 크기를 증가시키는 방향으로 작용하였고, 천립중 에 대해서는 세 대립유전자 모두가 증가시키는 방향으로 작용하 였다. $g w 2$ 는 수당립수에 관여하지 않았고 수수와 등숙률이 줄어드는데 영향을 미쳤으며, $g s 3$ 에 의해 수당립수와 수수에는 변이가 없었으나 등숙률은 감소하였다. $q s w 5$ 는 수당립수와 등숙률이 줄어드는데 관여하였으며 수수는 증가하는 방향으로 기여하였다. 대립유전자형 조합 중 $g w 2 g s 3 q s w 5$ 가 낟알 크기가 가장 켰고 $G W 2 G S 3 q S W 5$ 가 가장 작았다. GW2GS3qSW5를 보 유한 자원은 중원형 입형에 수당립수가 많고 등숙률이 높으며 정조 수량도 많았다. GW2gs $3 q S W 5$ 를 보유한 자원은 장립종이 면서 장폭비가 가장 큰 장원형 특성을 나타내 기존의 단립종 단원형인 우리나라 품종과는 입형 특성이 확연히 구별되었다. 개발된 입형 다양화 육종소재는 자포니카 입형 다양화 벼 품종개발을 위한 교배모본으로 육종사업에 실질적으로 적용 되고 있으며, 입형 및 수량 관련 형질 특성 분석과 입형 
관련 유전자와의 관련성 구명은 효율적인 육종사업을 위한 정보 로 활용되고 있다.

\section{사 사}

본 논문은 농촌진흥청 연구사업(과제번호: PJ01020201)의 지원에 의해 이루어진 것입니다. 대립형 유전자원 탐색 및 개발된 입형 다양화 육종소재 보존을 위해 협력하여 주신 농촌진흥청 국립농업과학원 농업유전자원센터 관계관께 깊은 감사를 드립 니다.

\section{REFERENCES}

1. Resurreccion A, Concepcion JC, Daygon VD, Mumm R, Reinke R, Dipti S, Bassinello PZ. 2014. Diversity of global rice markets and the science required for consumer-targeted rice breeding. PLoS ONE 9: e85106.

2. Choi HC, Kim YK, Cho SY, Moon HP, Park RK, Park NK, Kim KW, Shin YS, Choi YG, Kim YS. 1994. A new large-grain rice cultivar 'Daeripbbyeo 1'. Korean J Breed Sci 26: 453.

3. CODEX STAN 198-1995. 1995. Standard for rice.

4. Fan C, Xing Y, Mao H, Lu T, Han B, Xu C, Li X, Zhang Q. 2006. GS3, a major QTL for grain length and weight and minor QTL for grain width and thickness in rice, encodes a putative transmembrane protein. Theor Appl Genet 112: 1164-1171.

5. Fan C, Yu S, Wang C, Xing Y. 2009. A causal C-A mutation in the second exon of GS3 highly associated with rice grain length and validated as a functional marker. Theor Appl Genet 118: 465-472.

6. Fitzgerald MA, McCouch SR, Hall RD. 2009. Not just a grain of rice: the quest for quality. Trends Plant Sci 14: 133-139.

7. Ha KY, Kim BK, Ko JK, Shin MS, Kim KY, Ko JC, Baek MK, Kang HJ, Nam JK, Kim WJ. 2009. A medium-late, high yielding and good quality rice variety, 'Deureachan'. Kor J Breed Sci 41: 645-648.

8. Ha KY, Ko JK, Nam JK, Ko JC, Kim KY, Kang HJ, Shin MS, Baek MK, Kim BK, Kim WJ, Shin WC, Park HS. 2012. A new medium-late japonica rice cultivar, 'Boramchan' with super high yield. Kor J Breed Sci 44: 346-350.
9. Hansen J, Fuller F, Gale F, Crook F, Wailes E, Moore M. 2002. China's japonica rice market: growth and competitiveness. Rice situation and outlook yearbook.

10. Hirota O, Oka M, Takeda T. 1990. Sink activity estimation by sink size and dry matter increase during the ripening stage of barley (Hordeum vulgare) and rice (Oryza sativa). Ann Bot 65: 349-353.

11. Huang R, Jiang L, Zheng J, Wang T, Wang H, Huang Y, Hong Z. 2013. Genetic bases of rice grain shape: so many genes, so little known. Trends Plant Sci 18: 218-226.

12. Ishimaru K, Hirotsu N, Madoka Y, Murakami N, Hara N, Onodera H, Kashiwagi T, Ujiie K, Shimizu B, Onishi A. 2013. Loss of function of the IAA-glucose hydrolase gene TGW6 enhances rice grain weight and increases yield. Nature Genet 45: 707-711.

13. Juliano BO. 1979. The chemical basis of rice quality. In: Proceedings of the workshop on chemical aspects of rice grain quality, International Rice Research Institute, Los Banos, Philippines. pp. 69-90.

14. Kang HJ, Hwang IK, Kim KS, Choi HC. 2006. Comparison of the physicochemical properties and ultrastructure of japonica and indica rice grains. J Agri Food Chem 54: 4833-4838.

15. Kato T. 1986. Effects of the shading and rachis-branch clipping on the grain-filling process of rice cultivars differing in the grain size. Jpn J Crop Sci 55: 252-260.

16. Ko JK, Lee KW, Kim KJ, Baek MK, Shin WC, Chun JB, Kim WJ, Jeong JU, Kang KH, Kim HS, Kim BK. 2017. Quality differences in high grade of medium-short grain milled rice between the exported Korean rice and Chinese circulating rice in China. J Kor Soc Itnl Agric 29: 129-133.

17. Korea Seed and Variety Service (KSVS). 2005. The guidelines of characteristics for application and registration of new varieties in rice. Anyang. Korea. pp. 8, 14.

18. Koutroubas SD, Mazzini F, Pons B, Ntanos D. 2004. Grain quality variation and relationships with morpho-physiological traits in rice (Oryza sativa L.) genetic resources in Europe. Field Crop Res 86: 115-130.

19. Krishnan P, Ramakrishnan B, Raja Reddy K, Reddy V. 2011. High-temperature effects on rice growth, yield, and grain quality. Adv Agron 111: 87-206.

20. Kwak JE, Yoon MR, Lee JS, Lee JH, Ko SH, Tai TH, Won YJ. 2017. Morphological and starch characteristics of the Japonica rice mutant variety Seolgaeng for 
dry-milled flour. Food Sci Biotech 26: 43-48.

21. Lee CK, Kim JH, Shon JY, Yang WH, Yoon YH, Choi KJ, Kim KS. 2012. Impacts of climate change on rice production and adaptation method in Korea as evaluated by simulation study. Korean J Agric For Meteorol 14: 207-221.

22. Lee SY, Noh TH, Kim BK, Lee JH. 2003. Inheritance of grain weight and size of a high yielding japonica cultivar, Sobibyeo. Kor J Crop Sci 48: 142-146.

23. Li Y, Fan C, Xing Y, Jiang Y, Luo L, Sun L, Shao D, $\mathrm{Xu} \mathrm{C,} \mathrm{Li} \mathrm{X,} \mathrm{Xiao} \mathrm{J.} \mathrm{2011.} \mathrm{Natural} \mathrm{variation} \mathrm{in} \mathrm{GS5} \mathrm{plays}$ an important role in regulating grain size and yield in rice. Nature Genet 43: 1266-1269.

24. Li Z, Pinson SR, Stansel JW, Paterson AH. 1998. Genetic dissection of the source-sink relationship affecting fecundity and yield in rice (shape Oryza sativa L.). Mol Breed 4: 419-426.

25. Mao H, Sun S, Yao J, Wang C, Yu S, Xu C, Li X, Zhang Q. 2010. Linking differential domain functions of the GS3 protein to natural variation of grain size in rice. Proc Natl Acad Sci USA 107: 19579-19584.

26. Mo YJ, Jeung JU, Shin YS, Park CS, Kang KH, Kim BK. 2013. Agronomic and genetic analysis of Suweon 542 , a rice floury mutant line suitable for dry milling. Rice 6: 37.

27. Park HS, Ha KY, Kim KY, Kim WJ, Nam JK, Baek MK, Kim JJ, Jeong JM, Cho YC, Lee JH, Kim BK. 2015. Development of high-yielding rice lines and analysis of panicle and yield-related traits using doubled haploid lines derived from the cross between Deuraechan and Boramchan, high-yielding japonica rice cultivars in Korea. Kor J Breed Sci 47: 384-402.

28. Qi P, Lin YS, Song XJ, Shen JB, Huang W, Shan JX, Zhu MZ, Jiang L, Gao JP, Lin HX. 2012. The novel quantitative trait locus GL3.1 controls rice grain size and yield by regulating Cyclin-T1; 3. Cell Res 22: 1666-1680.

29. Rural Development Administration (RDA). 2012. Standard of analysis and survey for agricultural research. Suwon. Korea. p. 335.

30. Shim KC, Kang JW, Lee HS, Ahn SN. 2016. Elucidating the genetic basis of grain traits in japonica rice cultivar 'Daeripbyeo 1'. Kor J Breed Sci 48: 276-285.
31. Shomura A, Izawa T, Ebana K, Ebitani T, Kanegae H, Konishi S, Yano M. 2008. Deletion in a gene associated with grain size increased yields during rice domestication. Nature Genet 40: 1023-1028.

32. Song XJ, Huang W, Shi M, Zhu MZ, Lin HX. 2007. A QTL for rice grain width and weight encodes a previously unknown RING-type E3 ubiquitin ligase. Nature Genet 39: 623-630.

33. Standard evaluation system for rice (SES). 2014. International Rice Research Institute, Los Banos, Philippines. pp. 1-47.

34. Wang S, Wu K, Yuan Q, Liu X, Liu Z, Lin X, Zeng R, Zhu H, Dong G, Qian Q. 2012. Control of grain size, shape and quality by $O S S P L 16$ in rice. Nature Genet 44 : 950-955.

35. Wang S, Li S, Liu Q, Wu K, Zhang J, Wang S, Wang Y, Chen X, Zhang Y, Gao C. 2015. The OsSPL16-GW7 regulatory module determines grain shape and simultaneously improves rice yield and grain quality. Nature Genet 47: 949-954.

36. Weng J, Gu S, Wan X, Gao H, Guo T, Su N, Lei C, Zhang X, Cheng Z, Guo X. 2008. Isolation and initial characterization of $G W 5$, a major QTL associated with rice grain width and weight. Cell Res 18: 1199-1209.

37. Xing Y, Zhang Q. 2010. Genetic and molecular bases of rice yield. Annu Rev Plant Biol 61: 421-442.

38. Yan C, Yan S, Yang Y, Zeng X, Fang Y, Zeng S, Tian C, Sun Y, Tang S, Gu M. 2009. Development of gene-tagged markers for quantitative trait loci underlying rice yield components. Euphytica 169: 215-226.

39. Yan S, Zou G, Li S, Wang H, Liu H, Zhai G, Guo P, Song H, Yan C, Tao Y. 2011. Seed size is determined by the combinations of the genes controlling different seed characteristics in rice. Theor Appl Genet 123: 1173-1181.

40. Ying J, Gao J, Shan J, Zhu M, Shi M, Lin H. 2012. Dissecting the genetic basis of extremely large grain shape in rice cultivar 'JZ1560'. J Genet Genomics 39: 325-333.

41. Zuo J, Li J. 2014. Molecular genetic dissection of quantitative trait loci regulating rice grain size. Annu Rev Genet 48: 99-118. 